\title{
Evidence for the return of subducted continental crust in Samoan lavas
}

\author{
Matthew G. Jackson ${ }^{1}$, Stanley R. Hart ${ }^{2}$, Anthony A.P. Koppers ${ }^{3,4}$, Hubert Staudigel $^{3}$, \\ Jasper Konter ${ }^{3}$, Jerzy Blusztajn ${ }^{2}$, Mark Kurz ${ }^{2} \&$ Jamie A. Russell $^{3}$ \\ ${ }^{1}$ Massachusetts Institute of Technology - Woods Hole Oceanographic Institution Joint \\ Program, Woods Hole, MA 02543-1525, USA \\ ${ }^{2}$ Woods Hole Oceanographic Institution, Woods Hole, MA 02543-1525, USA \\ ${ }^{3}$ Scripps Institution of Oceanography, University of California, San Diego, La Jolla, CA \\ 92093-0225, USA \\ ${ }^{4}$ College of Oceanic \& Atmospheric Sciences, Oregon State University, Corvallis, OR \\ 97331-5503, USA
}

Substantial quantities of terrigenous sediments are known to enter the mantle at subduction zones, but little is known about their fate in the mantle ${ }^{1}$. Subducted sediment may be entrained in buoyantly upwelling plumes and returned to the earth's surface at hotspots ${ }^{2-5}$, but the proportion of recycled sediment in the mantle is small and clear examples of recycled sediment in hotspot lavas are rare ${ }^{6,7}$. We report here remarkably enriched ${ }^{87} \mathrm{Sr} /{ }^{86} \mathrm{Sr}$ and ${ }^{143} \mathrm{Nd} /{ }^{144} \mathrm{Nd}$ isotope signatures (up to 0.720830 and $\mathbf{0 . 5 1 2 2 8 5}$, respectively) in Samoan lavas from three dredge locations on the underwater flanks of Savai'i island, Western Samoa. The submarine Savai'i lavas represent the most extreme ${ }^{87} \mathrm{Sr} /{ }^{86} \mathrm{Sr}$ isotope compositions reported for ocean island basalts (OIBs) to date. The data are consistent with the presence of a recycled sediment component (with a composition similar to upper continental crust, or UCC) in the Samoan mantle. Trace element data show similar affinities with UCC — including exceptionally low $\mathrm{Ce} / \mathrm{Pb}$ and $\mathrm{Nb} / \mathrm{U}$ ratios ${ }^{8}$ — that complement the enriched ${ }^{87} \mathrm{Sr} /{ }^{86} \mathrm{Sr}$ and ${ }^{143} \mathrm{Nd} /{ }^{144} \mathrm{Nd}$ isotope signatures. The geochemical evidence from the new Samoan lavas radically redefines the 


\section{composition of the EM2 (enriched mantle 2) ${ }^{9}$ mantle endmember, and points to the presence of an ancient recycled UCC component in the Samoan plume.}

The earth's mantle, as sampled by OIBs erupted at hotspots, is chemically and isotopically heterogeneous. However, the origin of the geochemical heterogenteity of the mantle is not well understood. One model for the geochemical evolution of the mantle assumes that much of the chemical diversity is a result of subduction, a tectonic process that introduces enriched oceanic crust and compositionally heterogeneous sediment into a largely primitive (or slightly depleted) mantle ${ }^{5,10,11}$. Following subduction, these surface materials mix with a peridotitic mantle, thus imprinting their enriched chemical and isotopic signatures on its various domains. A number of isotopically-distinct geochemical reservoirs, as sampled by OIBs, have resulted from this process. The isotopic end-members are often referred to as HIMU (high ' $\mu$ ' or ${ }^{238} \mathrm{U} /{ }^{204} \mathrm{~Pb}$ ), EM1 (enriched mantle 1) and EM2 (enriched mantle 2) and DMM (depleted MORB [midocean ridge basalt] mantle $)^{9}$. While the most radiogenic $\mathrm{Pb}$ isotope ratios observed in the HIMU component have been proposed to result from a contribution of recycled oceanic crust $^{9,12}$, most models for the creation of the EM1 and EM2 mantle reservoirs invoke a small portion of lithologically distinct sediments that have been recycled into the mantle $e^{9,13}$.

The volcanically active Samoan Islands and seamounts define a hotspot track with a classical EM2 pedigree ${ }^{7,14,15}$. The first high precision ${ }^{87} \mathrm{Sr} /{ }^{86} \mathrm{Sr}$ and ${ }^{143} \mathrm{Nd} /{ }^{144} \mathrm{Nd}$ measurements from Samoan lavas were interpreted as evidence of sediment recycling 5 . Recently, however, the proposed recycled sediment origin of the enriched Samoan basalts 
has been called into question (see Supplementary Discussion), and an alternative model favoring source enrichment by metasomatic processes was proposed ${ }^{7}$. The extreme isotopic and chemical enrichment in the new Samoan EM2 lavas exhibit distinctly continental fingerprints, and argue for a role for a component similar to ancient recycled UCC in the Samoan plume (see Supplementary Discussion for ALIA dredge locations and geochemical data).

The most isotopically-enriched Samoan whole rock ${ }^{87} \mathrm{Sr} /{ }^{86} \mathrm{Sr}$ signature $(0.720469$, $\mathrm{Mg} \#=57.2)$ is recorded in a trachyandesite, dredge sample D115-21, which was taken from the southwestern flank of Savai'i. Clinopyroxene (cpx) mineral separates from the same sample yielded an even higher ${ }^{87} \mathrm{Sr} /{ }^{86} \mathrm{Sr}$ ratio (.721630). A trachybasalt (D115-18) hosts the second most enriched ${ }^{87} \mathrm{Sr} /{ }^{86} \mathrm{Sr}(0.718592, \mathrm{Mg} \#=58.7)$, and cpx mineral separates from the sample also gave more enriched ratios (0.720232-0.720830). Six other lavas recovered in the same dredge also exhibit enriched ${ }^{87} \mathrm{Sr} /{ }^{86} \mathrm{Sr}$ ratios $(0.708175$ 0.716394, Mg\#'s from 52.0-65.1). Dredge D118, located on the far western end of the Savai'i lineament, contained an alkali basalt with enriched ${ }^{87} \mathrm{Sr} /{ }^{86} \mathrm{Sr}(0.710337$, measured on fresh cpx). Dredge D128, taken on the northeastern flanks of Savai'i, yielded a transitional basalt with a high ${ }^{87} \mathrm{Sr} /{ }^{86} \mathrm{Sr}$ ratio $(0.712500, \mathrm{Mg} \#=70.5)$ and several other

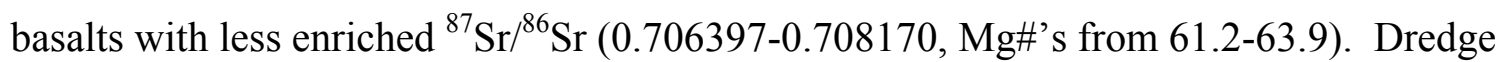
D114, taken on the southwestern flanks of Savai'i, provides younger shield basalts of transitional chemistry and normal ${ }^{87} \mathrm{Sr} /{ }^{86} \mathrm{Sr}(0.705422-0.705435, \mathrm{Mg \#}$ 's are 67.2 and 76.3).

The ${ }^{87} \mathrm{Sr} /{ }^{86} \mathrm{Sr}$ isotopes in the basalts from all three ultra-enriched sampling localitites are complemented by enriched (low) ${ }^{143} \mathrm{Nd} /{ }^{144} \mathrm{Nd}$ and the lowest ${ }^{3} \mathrm{He} /{ }^{4} \mathrm{He}$ ratios 
(4.31-4.93 times atmospheric, Ra) observed in Samoan basalts. Together the new data extend the Samoan isotope array to a region outside the global OIB field (Fig. 1). Highly enriched EM2 signatures have previously been observed only in metasomatized xenoliths from Savai'i $\left({ }^{87} \mathrm{Sr} /{ }^{86} \mathrm{Sr}\right.$ up to $\left.0.712838{ }^{16}\right)$, and the Samoan EM2 basalts provide the first evidence that the enriched component hosted in these xenoliths also occurs as erupted basalts. The enriched ${ }^{87} \mathrm{Sr} /{ }^{86} \mathrm{Sr}$ and ${ }^{143} \mathrm{Nd} /{ }^{144} \mathrm{Nd}$ isotope ratios, coupled with the low ${ }^{3} \mathrm{He} /{ }^{4} \mathrm{He}$, are consistent with a recycled UCC component in the mantle source of the Samoan EM2 basalts.

The UCC reservoir exhibits several diagnostic trace element characteristics that can be useful for detecting its presence in Samoan EM2 lavas. Compared to OIB and MORB lavas, UCC displays exceptional depletion in $\mathrm{Nb}$ (and $\mathrm{Ta}$ ), $\mathrm{Ti}$ and $\mathrm{Eu}$, and enrichment in $\mathrm{Pb}$ (Fig. 2). Samoan basalts have trace element characteristics that are increasingly similar to UCC with more enriched ${ }^{87} \mathrm{Sr} /{ }^{86} \mathrm{Sr}$ and ${ }^{143} \mathrm{Nd} /{ }^{144} \mathrm{Nd}$ values (Fig. 3). While the most depleted basalts from Samoa show slight positive anomalies in $\mathrm{Nb}$ and Ti, the magnitude of these anomalies decreases monotonically toward the most enriched Samoan EM2 basalts. Similarly, a correlation exists between greater Pb enrichment and increasing isotopic enrichment in Samoan basalts. Importantly, the Eu anomaly is increasingly negative in the most isotopically-enriched Samoan EM2 lavas (excluding basalts with $\mathrm{MgO}<6.5$ wt.\%), and the $\mathrm{Rb} / \mathrm{Sr}$ and $\mathrm{U} / \mathrm{Pb}$ are too low in the lower (or middle) continental crust $^{17}$ to be consistent with the new Samoan $\mathrm{Sr}$ and $\mathrm{Pb}$ isotope data; these observations rule out the involvement of lower (or middle) continental crust. Furthermore, rare xenoliths with enriched ${ }^{87} \mathrm{Sr} /{ }^{86} \mathrm{Sr}$ and ${ }^{143} \mathrm{Nd} /{ }^{144} \mathrm{Nd}$ from the subcontinental lithospheric mantle (SCLM $)^{9}$ suggest that this mantle domain can be 
isotopically-enriched. However, the SCLM does not appear to exhibit the trace element anomalies observed in the most isotopically-enriched Samoan lavas ${ }^{18}$. Instead, isotope ratios and trace element anomalies $(\mathrm{Nb}, \mathrm{Ti}, \mathrm{Eu}$ and $\mathrm{Pb})$ in Samoan basalts generate arrays that trend toward a composition similar to UCC.

We can exclude a shallow origin for the anomalous enrichment observed in the Samoan EM2 lavas. Due to the close proximity of the Tonga Trench, located only 120 $\mathrm{km}$ south of Savai'i, rapid cycling of sediment from the subduction zone into the Samoan plume was proposed as a mechanism for generating the extreme isotopic enrichment in Samoan lavas ${ }^{14}$. However, at the time the submarine Savai'i lavas were erupted $5 \mathrm{Ma}$ ago (A.K. et al., manuscript in preparation), plate reconstructions indicate that the northern terminus of the Tonga Trench was located $1,300 \mathrm{~km}$ to the west of Savai' ${ }^{19}{ }^{19}$, and sediment input from the Tonga Trench can be ruled out as a source of enrichment in these lavas.

Evidence from $\mathrm{Pb}$ isotopes suggests that it is unlikely that shallow level contamination by modern marine sediments is responsible for the isotopic enrichment in the Samoan EM2 basalts. In $\Delta^{207} \mathrm{~Pb} /{ }^{204} \mathrm{~Pb}-\Delta^{208} \mathrm{~Pb} /{ }^{204} \mathrm{~Pb}$ isotope space, Samoan basalts and global marine sediments ${ }^{1}$ exhibit non-overlapping fields with diverging trends (Fig. 4). Moreover, three composite cores taken from the Samoan region, and a single ferromanganese crust from the flanks of Savai'i, plot in the global marine sediment field and exhibit no geochemical relationship with the extremely enriched Samoan lavas. It is also unlikely that the Samoan plume has been contaminated by stranded continental crust, such as found beneath the Kerguelen plateau ${ }^{20}$ and the southern Mid-Atlantic ridge ${ }^{21}$, 
or by ancient limestone blocks like those discovered in the Romanche fracture zone ${ }^{22}$. The tectonic history of the Samoan region neither places it at the locus of continental rifting, which was responsible for the marooned Kerguelen and southern Atlantic continental blocks, nor does it place Samoa in proximity to any Pacific fracture zones ${ }^{23}$.

Large quantities of sediment derived from UCC have entered the mantle at subduction zones over geologic time ${ }^{1}$, and such a reservoir is ideally suited as an enriched source for the Samoan plume. The array formed by the Samoan EM2 basalts in ${ }^{143} \mathrm{Nd} /{ }^{144} \mathrm{Nd}-{ }^{87} \mathrm{Sr} /{ }^{86} \mathrm{Sr}$ isotope space is anchored on the depleted end by basalts from Ta' $\mathrm{u}$, one of the youngest, easternmost Samoan Islands. The ${ }^{143} \mathrm{Nd} /{ }^{144} \mathrm{Nd}-{ }^{87} \mathrm{Sr} /{ }^{86} \mathrm{Sr}$ array suggests mixing between this dominant, slightly depleted Ta'u component and a rare, enriched component that exhibits isotope and trace element characteristics similar to UCC. The proportion of the enriched component in the Samoan EM2 lavas can be estimated by calculating trace element concentrations in the depleted Ta'u mantle and mixing this composition with UCC (see Supplementary Discussion). A contribution of 5\% UCC to the depleted Ta'u mantle generates a composition that, following mixing and melting, produces a trace element pattern similar to that observed in Samoan EM2 sample D115-18 (with ${ }^{87} \mathrm{Sr} /{ }^{86} \mathrm{Sr}$ of 0.718592). Fixing the proportions of the depleted and UCC components in the Samoan EM2 source in this way then defines the ${ }^{87} \mathrm{Sr} /{ }^{86} \mathrm{Sr}$ and ${ }^{143} \mathrm{Nd} /{ }^{144} \mathrm{Nd}$ isotopic composition of this material, which is 0.7421 and 0.5117 , respectively. The most isotopically-enriched Samoan lavas have higher ${ }^{87} \mathrm{Sr} /{ }^{86} \mathrm{Sr}$ than average continental crust inferred from suspended river sediments $\left({ }^{87} \mathrm{Sr} /{ }^{86} \mathrm{Sr} \sim 0.716^{24}\right)$ and global marine sediments $\left(\sim 0.717^{1}\right)$, values that are biased toward younger continental crust. However, composites of directly sampled ancient continental shield rocks show 
isotopically-enriched compositions ${ }^{25}$ that bracket the calculated composition of the recycled UCC sediment in the Samoan mantle. The new ultra-enriched EM2 lavas suggest an unusually-enriched recycled protolith in the Samoan mantle.

Despite the large volumes of sediment entering the mantle at subduction zones (estimated at 0.5 to $0.7 \mathrm{~km}^{3} /$ year ${ }^{1}$ ), isotopic signatures associated with recycled UCC are rare in $\mathrm{OIBs}^{26}$. This enriched component is also uncommon in the Samoan plume, where the highly enriched Samoan EM2 lava D115-18 is calculated to have only 5\% recycled UCC (and $95 \%$ depleted Ta'u source), and $90 \%$ of the remaining Samoan basalts exhibit depleted ${ }^{143} \mathrm{Nd} /{ }^{144} \mathrm{Nd}$ ratios $(>0.512638)$. In addition to being rare in other OIBs, recycled UCC may exist in low abundance in the Samoan plume. The reason for this may be that most subducted sediment melts and is rapidly returned to the surface in subduction zone volcanoes, or is simply scraped off onto the forearc and is never subducted. Alternatively, if a significant portion of UCC has been subducted over the past $4 \mathrm{Ga}\left(0.5-0.7 \mathrm{~km}^{3} / \mathrm{yr}\right)$ and has survived subduction zone melting, the resulting accumulated reservoir in the mantle will constitute only $\sim 0.15 \%$ of its mass. Such a small reservoir may be diluted by the ambient mantle following convective stirring, a mechanism that efficiently attenuates mantle heterogeneities. Therefore, recycled crustal signatures can be greatly diluted and difficult to detect. By contrast, the recycled UCC component in the Samoan plume is an anomalous survivor in a chaotic mantle.

Supplementary Information is linked to the online version of the paper at www.nature.com/nature.

Acknowledgements. Thanks to A. Hofmann and W. White for very helpful reviews. We thank N. Shimizu, R. Workman and R. Rudnick for discussion, and J. Natland for sharing his unpublished data. This study was supported by National Science Foundation grants. We are grateful to the scientific party and 
ships crew of the R/V Kilo Moana for the success of the ALIA 2005 expedition (earthref.org/ERESE/projects/ALIA/).

Author Contribution. M.J. performed most of the experimental work, developed the model and wrote the paper. S.H. and H.S. conceived of the project, and were co-chiefs of the ALIA expedition. A.K. and J.K. were responsible for the cruise bathymetry, and A.K. greatly improved the figures. J.B. and M.K. provided analytical assistance and access to facilities. A.K., J.B., J.K. and J.R. helped with sample preparation. All authors participated in the discussion and interpretation of results, and commented on the manuscript.

Author Information. Reprints and permissions information is available at www.nature.com/reprints. The authors declare no competing financial interests. Correspondence should be addressed to M.G.J. (mjackson@whoi.edu). 
Figure Legends

Figure $1{ }^{87} \mathrm{Srl}{ }^{86} \mathrm{Sr}$ and ${ }^{143} \mathrm{Nd} /{ }^{144} \mathrm{Nd}$ isotope ratios of new enriched Samoan lavas, compared with other Samoan shield basalts ${ }^{7}$, global OIB compositions and GLOSS (Global Subducting Sediment) ${ }^{1}$. Analyses where whole rock (w) powders and cpx (c) analyses are performed on the same sample are connected by a tie-line. A model mixing line between depleted Ta'u peridotite and UCC is marked at $1 \%$ intervals, with increasing contribution from the latter component. The hypothetical UCC mixing endmember lies outside of the figure. Approximately $5 \%$ UCC is required to produce the spidergram of sample D115-18 (see Supplementary Discussion), and $\sim 6 \%$ is required to generate the ${ }^{87} \mathrm{Sr} /{ }^{86} \mathrm{Sr}$ and ${ }^{143} \mathrm{Nd} /{ }^{144} \mathrm{Nd}$ in $\mathrm{D} 115-21$.

Figure 2 Primitive mantle normalized ${ }^{27}$ trace element patterns for the Samoan EM2 endmember. The EM2 spidergram is the most isotopicallyenriched Samoan lava, sample D115-21 $\left({ }^{87} \mathrm{Sr} /{ }^{86} \mathrm{Sr}=0.720469, \mathrm{Mg} \#=57\right)$. The other mantle endmembers (corrected to Mg\#'s 60-62) and UCC ${ }^{17}$ are plotted for comparison. Similar to UCC, the Samoan EM2 lava exhibits large negative Ti and $\mathrm{Nb}$ (and $\mathrm{Ta}$ ) anomalies and an excess of $\mathrm{Pb}$ (and $\mathrm{K}$ ).

Figure $3{ }^{87} \mathrm{Srl} /{ }^{86} \mathrm{Sr}$ and ${ }^{143} \mathrm{Nd} /{ }^{144} \mathrm{Nd}$ ratios plotted against diagnostic UCC trace element indicators in Samoan basalts, suggesting the presence of a 
UCC component in Samoan EM2 lavas. More enriched Samoan basalts exhibit trace element characteristics that are increasingly similar to UCC. UCC ${ }^{17}$ plots outside the panels, and its trace element and isotopic composition is indicated by the level (and direction) of the arrows. a-c, all submarine Savai'i samples are plotted, as are other Samoan shield lavas with $\mathrm{MgO}>6.5$ wt.\%. d, submarine Savai'i samples with $\mathrm{MgO}<6.5 \%$ are excluded (avoiding possible affects of plagioclase fractionation). All trace element data shown are by ICP. Element anomalies are calculated as follows ( $\mathrm{N}=$ Normalized to Primitive Mantle ${ }^{27}$ ):

$\mathrm{Ti} / \mathrm{Ti}^{*}=\mathrm{Ti}_{N} /\left(\mathrm{Nd}_{\mathrm{N}}{ }^{-0.0555} \times \mathrm{Sm}_{\mathrm{N}}{ }^{0.333} \times \mathrm{Gd}_{\mathrm{N}}{ }^{0.722}\right), \mathrm{Nb} / \mathrm{Nb}^{*}=\mathrm{Nb}_{N} / \sqrt{ }\left(\mathrm{Th}_{N} \times \mathrm{La}_{\mathrm{N}}\right), \mathrm{Eu} / \mathrm{Eu}^{*}=$ $E u_{N} / \sqrt{ }\left(S m_{N} \times G d_{N}\right)$.

Figure 4 Delta $\mathrm{Pb}$-isotope compositions of Samoan lavas and marine sediment samples indicate that the Samoan EM2 lavas are not contaminated with modern marine sediment. Samoan basalts show no overlap with oceanic sediments contributing to GLOSS ${ }^{1}$ (purple squares), composite sections from three sediment cores taken in the Samoan region (blue circles), and a Samoan ferromanganese rind (blue diamond). Pb-isotope data for endmember MORB (normal segments) ${ }^{28}$, EM1 (Pitcairn), HIMU (Mangaia and Tubuai) are from the literature. The use of delta $\mathrm{Pb}$-isotope notation ${ }^{29}$ to identify sediment components in OIB basalts is discussed elsewhere ${ }^{30}$. All Samoan data shown are by a high precision Tl-spike protocol ${ }^{7}$. 
1. Plank, T. \& Langmuir, C. H. The chemical compositions of subducting sediments and its consequences for the crust and mantle. Chem. Geol. 145, 325-394 (1998).

2. Allegre, C.J. \& Turcotte, D.L. Geodynamic mixing in the mesosphere boundary layer and the origin of oceanic islands. Geophys. Res. Lett. 12, 207-210 (1985).

3. Cohen, R.S. \& O'Nions, R.K. Identification of recycled continental material in the mantle from $\mathrm{Sr}, \mathrm{Nd}$ and $\mathrm{Pb}$ isotope investigations. Earth Planet. Sci. Lett. 61, 73-84 (1982).

4. Hawkesworth, C.J., Norry, M.J., Roddick, J.C. \& Vollmer, R. ${ }^{143} \mathrm{Nd} /{ }^{144} \mathrm{Nd}$ and ${ }^{87} \mathrm{Sr} /{ }^{86} \mathrm{Sr}$ ratios from the Azores and their significance in LIL-element enriched mantle. Nature 280, 28-31 (1979).

5. White, W.M. \& Hofmann, A.W. Sr and Nd isotope geochemistry of oceanic basalts and mantle evolution. Nature 296, 821-825 (1982).

6. White, W.M. \& Duncan, R.A. in Earth Processes: Reading the Isotopic Code (eds Basu, A. \& Hart, S.R.) 183-206 (Geophys. Monogr. 95, AGU, Washington DC, 1996). 7. Workman, R.K. et al. Recycled metasomatized lithosphere as the origin of the Enriched Mantle II (EM2) endmember: Evidence from the Samoan volcanic chain. Geochem. Geophys. Geosyst. 5, \#2003GC000623 (2004).

8. Hofmann, A.W., Jochum, K.P., Seufert, M. \& White, W.M. Nb and Pb in oceanic basalts: new constraints on mantle evolution. Earth Planet. Sci. Lett. 79, 33-45 (1986). 9. Zindler, A. \& Hart, S.R. Chemical Geodynamics. Ann. Rev. Earth Planet. Sci. 14, 493-571 (1986). 
10. Hofmann, A.W. \& White, W.M. Mantle plumes from ancient oceanic crust. Earth Planet. Sci. Lett. 57, 421-436 (1982).

11. Chase, C.G. Oceanic island Pb: two-stage histories and mantle evolution. Earth Planet. Sci. Lett. 52, 277-284 (1981).

12. Zindler, A., Jagoutz, E. \& Goldstein, $\mathrm{S} . \mathrm{Nd}, \mathrm{Sr}$ and $\mathrm{Pb}$ isotopic systematics in a threecomponent mantle: a new perspective. Nature 298, 519-523 (1982).

13. Weaver, B. L. The origin of ocean island basalt end-member compositions: Trace element and isotopic constraints. Earth Planet. Sci. Lett. 104, 381-397 (1991).

14. Farley, K.A., Natland, J.H., \& Craig, H. Binary mixing of enriched and undegassed (primitive?) mantle components (He, $\mathrm{Sr}, \mathrm{Nd}, \mathrm{Pb})$ in Samoan lavas. Earth Planet. Sci. Lett. 111, 183-199 (1992).

15. Wright, E. \& White, W.M. The origin of Samoa: new evidence from $\mathrm{Sr}, \mathrm{Nd}$ and $\mathrm{Pb}$ isotopes. Earth Planet. Sci. Lett. 82, 151-162 (1987).

16. Hauri, E.H., Shimizu, N., Dieu, J., \& Hart, S.R. Evidence for hotspot-related carbonatite metasomatism in the oceanic upper mantle. Nature 365, 221-227 (1993).

17. Rudnick, R. L. \& Gao, S. in The Crust (ed. Rudnick, R. L.) 1-64 (Treatise in Geochemistry, Vol. 3, Elsevier, Amsterdam, 2003).

18. McDonough, W.F. Constraints on the composition of the continental lithospheric mantle. Earth Planet. Sci. Lett 101, 1-18 (1990).

19. Hart, S.R. et al. Genesis of the Western Samoa seamount province: age, geochemical fingerprint and tectonics. Earth Planet. Sci. Lett. 227, 37-56 (2004). 
20. Frey, F.A., Weis, D., Borisova, A.Y., \& Xu, G. Involvement of continental crust in the formation of the Cretaceous Kerguelen Plateau: New Perspectives from ODP Let 120 Sites. J. Petrol. 43, 1207-1239 (2002).

21. Kamenetsky, V.S. et al. Remnants of Gondwanan continental lithosphere in oceanic upper mantle: evidence from the South Atlantic Ridge. Geology 29, 243-246 (2001).

22. Bonatti, E. et al. Lower Cretaceous deposits trapped near the equatorial Mid-Atlantic Ridge. Nature 380, 518-520 (1996).

23. Taylor, B. The single largest oceanic plateau: Ontong Java-Manihiki-Hikurangi, Earth Planet. Sci. Lett. 241, 372-380 (2006).

24. Goldstein, S.J. \& Jacobsen, S.B. Nd and Sr isotopic systematics of river water suspended material: implications for crustal evolution. Earth Planet. Sci. Lett. 87, 249265 (1988).

25 McCulloch, M.T. \& Wasserburg, G.J. Sm-Nd and Rb-Sr chronology of continental crust formation. Science 200, 1003-1011 (1978).

26. Hofmann, A.W. Mantle geochemistry: The message from oceanic volcanism. Nature 385, 219-229 (1997).

27. McDonough, W.F. \& Sun, S.S. The composition of the Earth. Chem. Geol. 120, 223-253 (1995).

28. Su, Y. Global MORB chemistry compilation at the segment scale Thesis, Columbia Univ. (2003).

29. Hart, S. R. A large-scale isotope anomaly in the Southern Hemisphere mantle. Nature 309, 753-757 (1984). 
30. Hart, S.R. Heterogeneous mantle domains: signatures, genesis and mixing chronologies. Earth Planet. Sci. Lett. 90, 273-296 (1988). 


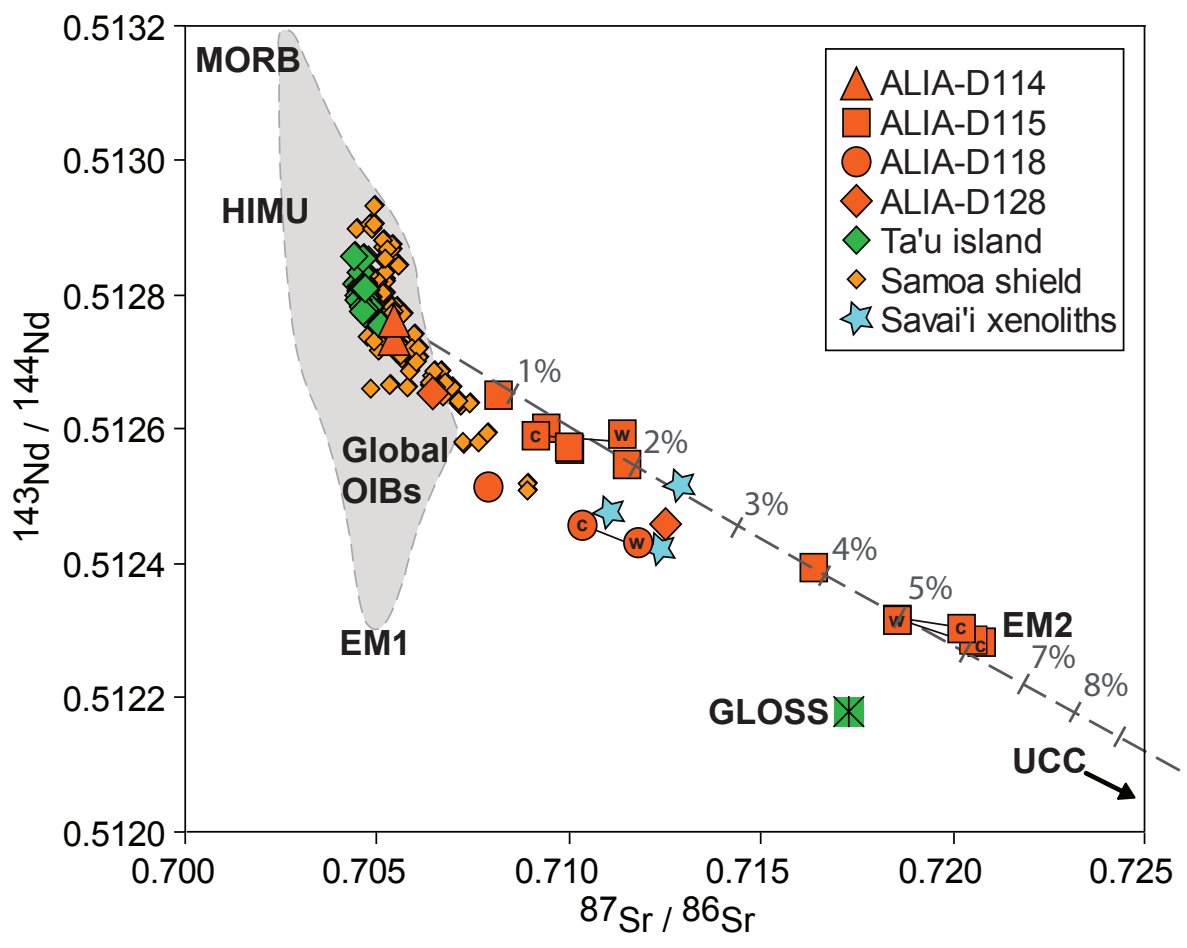

2007-01-00868 Figure 1 


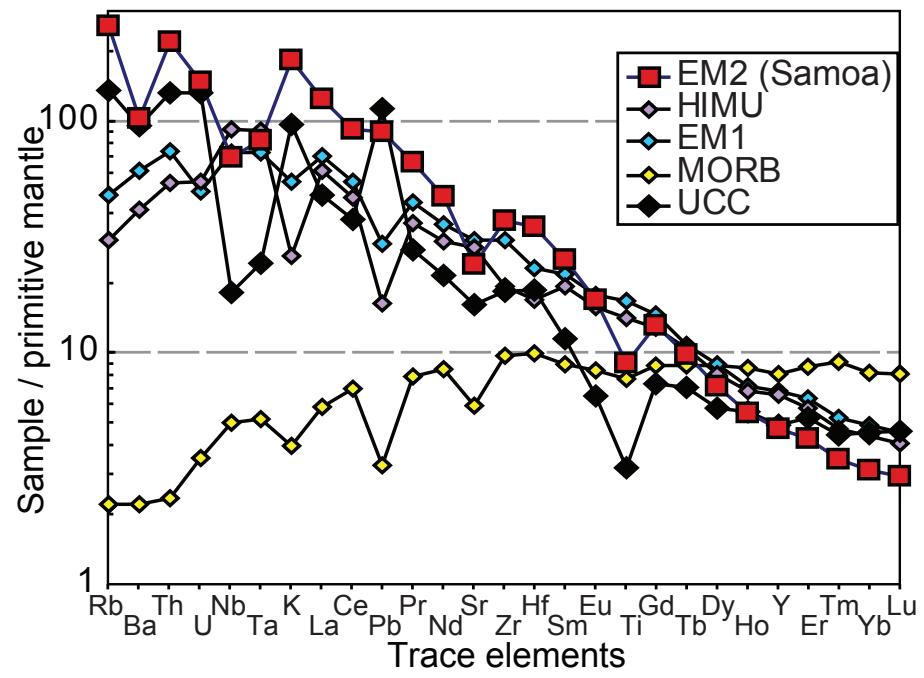

2007-01-00868 corr'd Figure 2 

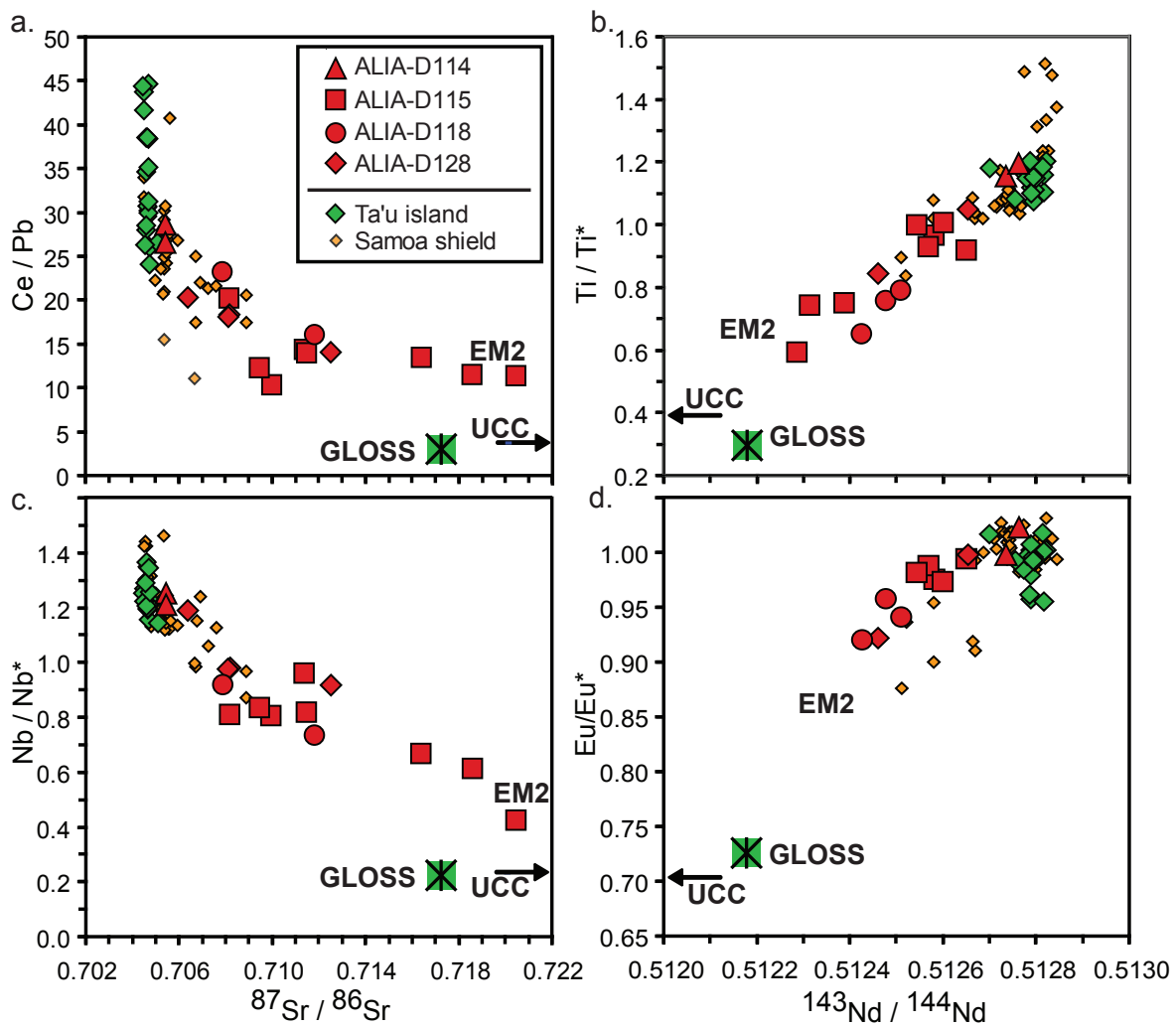

2007-01-00868 corr'd Figure 3 


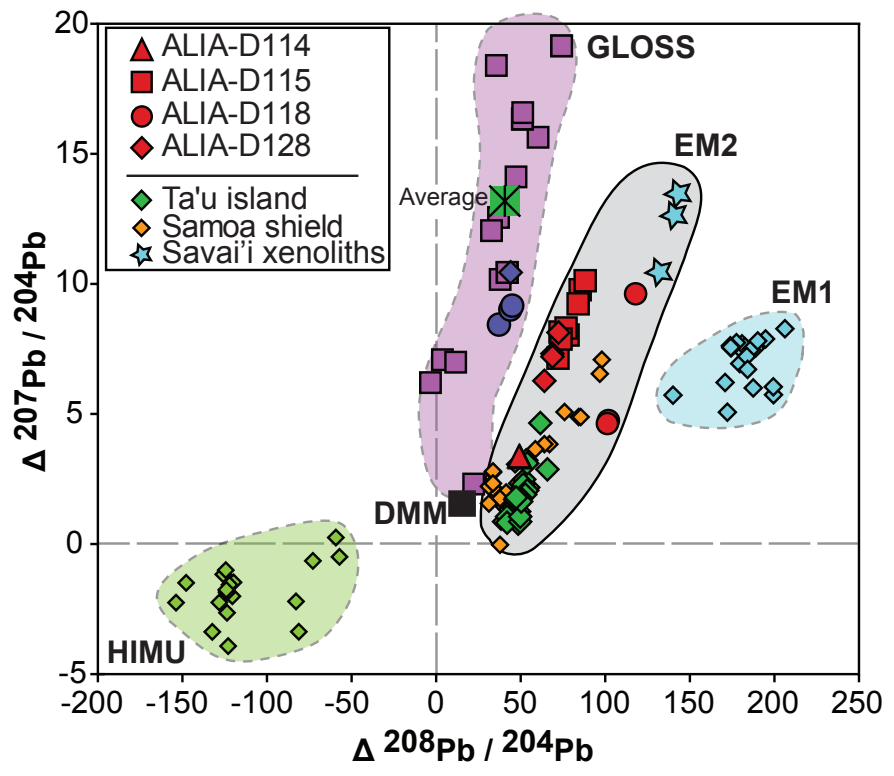

2007-01-00868 Figure 4 


\section{SI Guide}

Contents of Supplementary Information (in a merged PDF titled jacksonsuppinfo.pdf; Size: $0.7 \mathrm{MB}$ total):

1. Supplementary Discussion

2. Supplementary Figure 1 and caption

3. Supplementary Figure 2 and caption

4. Supplementary Figure 3 and caption

5. Supplementary Figure 4 and caption

6. Supplementary Table 1

7. Supplementary Table 2

8. Supplementary Table 3

The file contains a Supplementary Discussion that gives a model of the Samoan EM2 source, including calculations and assumptions. The file also contains a Supplementary Table 1 and a Supplementary Table 2 that together provide the model parameters used to calculate the depleted Ta'u and EM2 Samoan sources, respectively. The file also contains a Supplementary Table 3 that provides the new Samoan geochemical data. Four supplementary figures also are included in the file: Supplementary Figure 1 shows new helium isotope data from the remarkably enriched Samoan lavas; Supplementary Figure 2 is an expanded view of main text Figure 1, and shows the composition of the Samoan lavas in the context of individual samples from the upper continental crust; Supplementary Figure 3 compares the spidergram of a model melt of the EM2 source with the spidergram of an isotopically-enriched Samoan EM2 lava. Supplementary Figure 4 provides a model that explains the correlation between $\mathrm{SiO}_{2}$ and ${ }^{87} \mathrm{Sr} /{ }^{86} \mathrm{Sr}$ in lavas from dredge ALIA D115. 


\section{Supplementary Discussion}

Recycled UCC in the Samoan EM2 mantle. The standard model for the genesis of the EM2 reservoir suggests a role for recycled sediment, probably terrigenous in origin ${ }^{1-7}$. However, a number of problems with the standard model were outlined in ref. 8, and an alternative origin of the Samoan EM2 source (recycled, metasomatized lithosphere) was proposed. In light of the remarkably enriched Samoan lavas presented in this paper, we reconsider the arguments against a recycled terrigenous component in the EM2 plume. We demonstrate that recycled upper continental crust (UCC) can have an important role in the origin of the EM2 source. However, we maintain that it is (most likely) not "upper continental crust" (UCC) that is being recycled, but sediment with a composition resembling that of UCC. While the sediment recycling model presented here does not invalidate the metasomatic model for the lavas presented earlier ${ }^{8}$, the new lavas presented in this study are consistent with a recycled sediment component.

The problems with recycled marine sediment in the Samoan EM2 mantle source (as outlined in ref. 8) are as follows. The variation in ${ }^{187} \mathrm{Os} /{ }^{188} \mathrm{Os}$ in Samoan lavas is not consistent with mixing between recycled marine sediment and depleted MORB mantle (DMM). Such a scenario would require 35\% marine sediment in the EM2 source, a quantity not observed in the trace element patterns of Samoan basalts. Additionally, the smooth trace element spidergrams observed in Samoan EM2 lavas were suggested to be inconsistent with a sediment component in the Samoan EM2 source. This is because, unlike Samoan EM2 lavas presented earlier ${ }^{8}$, marine sediments exhibit "jagged" spidergrams, marked by large negative anomalies for $\mathrm{Nb}$ (and $\mathrm{Ta}$ ), $\mathrm{Ti}$ and $\mathrm{Eu}$ and large positive anomalies for $\mathrm{Pb}$ (and $\mathrm{K}$ ). It was also noted that $\mathrm{EM} 2$ lavas exhibit negative Ba- 
anomalies, a feature not characteristic of marine sediments ${ }^{8}$. Furthermore, because EM2 lavas exhibit high ${ }^{3} \mathrm{He} /{ }^{4} \mathrm{He}$ ratios ( $\sim 8 \mathrm{Ra}$, ratio to atmosphere, or $\left.\sim 1.4 \times 10^{-6}\right)$, a trait not shared with the low ${ }^{3} \mathrm{He} /{ }^{4} \mathrm{He}$ ratios in sediments $(0.05-1 \mathrm{Ra})^{9}$ and continental crust $(0.007$ $\mathrm{Ra})^{10}$, it was suggested that the Samoan EM2 source does not host a sediment component ${ }^{8}$. Finally, $\mathrm{Pb}$-isotope composition of modern marine sediment was observed to be unsuitable as an endmember for the enriched Samoan basalts ${ }^{8}$ : Modern marine sediments exhibit ${ }^{208} \mathrm{~Pb} /{ }^{204} \mathrm{~Pb}$ ratios that are too low at a given ${ }^{206} \mathrm{~Pb} /{ }^{204} \mathrm{~Pb}$ to serve as mixing endmembers for the Samoan EM2 lavas.

Below, we suggest that, instead of a marine sediment composition such as GLOSS (Global Subducting Sediment ${ }^{11}$ ), sediment with a composition like UCC (a composition here approximated by UCC from ref. 12) is more suitable for generating a source sampled by the most isotopically-enriched Samoan lavas. A small portion $(\sim 5 \%)$ of (sediment with the composition of) UCC mixed with a depleted Samoan plume component generates a peridotite that, when melted, produces a spidergram similar to that observed in the most isotopically-enriched Samoan lavas. Like Samoan EM2 lavas, UCC exhibits a negative Ba anomaly, a feature not shared with GLOSS ${ }^{11}$. Furthermore, published Os-isotopes ${ }^{8}$ in enriched Samoan EM2 lavas are not inconsistent with a UCC component in the plume. The Os-isotope signature in Samoan basalts is not likely a result of mixing between DMM $\left({ }^{187} \mathrm{Os} /{ }^{188} \mathrm{Os}=0.125\right)$ and marine sediment; however, a mixture of $\mathrm{UCC}\left({ }^{187} \mathrm{Os} /{ }^{188} \mathrm{Os}=1.05,[\mathrm{Os}]=30 \mathrm{ppt}^{13}\right)$ and a depleted Samoan plume component generates a mixing trend that describes the Os-isotope data for Samoan shield basalts (excluding samples with $<100 \mathrm{ppt}$ Os, and assuming measurement precision of $\pm 1.5 \%$ in data from ref. 8). This mixing scenario uses measured Ta ${ }^{\prime}{ }^{187} \mathrm{Os} /{ }^{188} \mathrm{Os}$ ratios 
of $0.129^{8}$ and assumes that the Ta'u peridotite source also has Os concentrations that are depleted relative to primitive mantle $\left(>3,900 \mathrm{ppt}^{14}\right)$. Moreover, new helium isotope data for Samoan EM2 lavas exhibit low ratios $(<5 \mathrm{Ra})$ that plot on a trajectory that trends to $\mathrm{UCC}$, and are consistent with the existence of a recycled UCC component in the Samoan plume (Supplementary Figure 1). Finally, our model for the formation of the EM2 mantle agrees with $\mathrm{Pb}$-isotope constraints. $\mathrm{UCC}$ exhibits a large range of $\mathrm{Pb}$-isotope values, and the Samoan EM2 lavas exhibit Pb-isotope values that plot in the field previously defined for $\mathrm{UCC}^{15}$.

Model for the EM2 source. In order to model the generation of the mantle source sampled by the new Samoan EM2 lavas, we take advantage of the array formed by Samoan basalts in ${ }^{87} \mathrm{Sr} /{ }^{86} \mathrm{Sr}-{ }^{143} \mathrm{Nd} /{ }^{144} \mathrm{Nd}$ isotope space. The array suggests that the most enriched Samoan basalts were formed as products of mantle-mixing between a depleted component (here represented by the mantle source sampled by the isotopically-depleted and remarkably homogeneous lavas from Ta'u island) and a component similar to UCC (Supplementary Figure 2). In order to determine the proportion of UCC in the Samoan plume, we first calculate a trace element peridotite source for the depleted Ta'u endmember that is consistent with the radiogenic isotopes of $\mathrm{Nd}, \mathrm{Hf}, \mathrm{Sr}$ and $\mathrm{Pb}$. We then determine the amount of UCC that must be added to the depleted Ta'u peridotite source so that the final mixture, an enriched peridotite, can be melted to generate a spidergram similar to the new Samoan EM2 lavas.

In the following modeling exercise, we generate a model for the EM2 source that describes the array formed by the most isotopically-enriched submarine Savai'i lavas from dredge D115, and we make no attempt to model the other components previously 
identified $^{8}$ in lavas from the Samoan hotspot. We emphasize that the model is just one possible model that is consistent with the isotopes and trace elements in Samoan EM2 lavas. The model is presented only to demonstrate that recycling sediment into Samoan EM2 lavas is possible.

Composition of the depleted Ta'u peridotite source. Following ref. 8, we generate an average olivine fractionation corrected trace element budget for Ta'u lavas (Supplementary Figure 3 and Supplementary Table 1). In order to determine a trace element mantle source sampled by the average Ta'u lava composition, we first assume a peridotite source lithology, an aggregated fractional melting model, and we adopt mineral-melt partition coefficients from ref. 16 (Supplementary Table 1). We also assume a two-stage isotope model for the evolution of the depleted Ta'u source, and that this differentiation event of a primitive mantle composition occurred at $1.8 \mathrm{Ga}$. This age is commonly quoted as the average mantle differentiation age ${ }^{17}$, and is an age that is consistent with the array formed by Ta'u lavas in ${ }^{207} \mathrm{~Pb} /{ }^{204} \mathrm{~Pb}$ vs. ${ }^{206} \mathrm{~Pb} /{ }^{204} \mathrm{~Pb}$ isotope space (see Fig. 7 in ref. 8). Given these assumptions, a Ta'u source is calculated so that parentdaughter ratios- $\mathrm{Sm} / \mathrm{Nd}$ and $\mathrm{Lu} / \mathrm{Hf}$ - will generate the present-day depleted ${ }^{143} \mathrm{Nd} /{ }^{144} \mathrm{Nd}$ (Ta'u average is $0.512789^{8}$ ) and ${ }^{176} \mathrm{Hf} /{ }^{177} \mathrm{Hf}\left(\mathrm{Ta}{ }^{\prime} u\right.$ average is $0.282987^{18}$ ) isotopes measured in Ta'u lavas given the two-stage isotope model. The Ta'u source is not very sensitive to its age of formation: ages of 1.0-2.5 Ga require only small variations in melting - 4.5 to $5.5 \%$ - to generate the average Ta'u lava. However, assuming a formation age of $1.8 \mathrm{Ga}$, a $5.1 \%$ melt (with $\sim 50.6 \%$ garnet melting) of the hypothetical Ta'u source will generate a model melt with a spidergram that is both identical to the average measured Ta'u lava and consistent with isotopic constraints. These highly 
specific melting parameters are presented only to generate an average Ta'u source that is consistent with isotopic constraints, and by presenting them we are not suggesting such precise knowledge of the actual mantle "plumbing" beneath Ta'u island.

The ${ }^{87} \mathrm{Sr} r{ }^{86} \mathrm{Sr}$ of primitive mantle is unconstrained, so it is not possible to evaluate whether the ${ }^{87} \mathrm{Sr} /{ }^{86} \mathrm{Sr}$ measured in Ta'u lavas is enriched or depleted relative to primitive mantle. However, the average ${ }^{87} \mathrm{Sr} /{ }^{86} \mathrm{Sr}$ in Ta'u lavas $(0.704650)$ and the $\mathrm{Rb} / \mathrm{Sr}$ of the Ta'u source (0.0268) can be modeled as having evolved from primitive mantle at $1.8 \mathrm{Ga}$ if the present-day primitive mantle ${ }^{87} \mathrm{Sr} /{ }^{86} \mathrm{Sr}$ is 0.70508 , a value that is in the range typically assigned to primitive mantle. In order for the two-stage isotope model to produce the observed average $\mathrm{Ta}{ }^{\prime}{ }^{206} \mathrm{~Pb} /{ }^{204} \mathrm{~Pb}(19.271)$ and ${ }^{206} \mathrm{~Pb} /{ }^{204} \mathrm{~Pb}(15.597)$ (excluding T14 and considering only Tl-spiked data ${ }^{8}$ ), the proportion of sulfide ${ }^{19}$ in the Ta'u source mineralogy is adjusted to obtain an appropriate parent-daughter $\mathrm{U} / \mathrm{Pb}$ source ratio. The resulting calculated $\mathrm{Th} / \mathrm{Pb}$ source ratio is within error of the $\mathrm{Th} / \mathrm{Pb}$ ratio required to produce the average $\mathrm{Ta}^{\prime} \mathrm{u}{ }^{208} \mathrm{~Pb} /{ }^{204} \mathrm{~Pb}$ composition (39.424) in $1.8 \mathrm{Ga}$. While non-unique (a different melt model could be chosen or the Ta'u source formation age may be different, etc.), the trace element source calculated from Ta'u lavas is consistent (within the uncertainties of the data) with constraints from radiogenic isotopes.

Generation of a source for the Samoan EM2 lavas. Determining the precise nature of the recycled component contributing to the enrichment in the Samoan plume is not straightforward. UCC rocks and individual marine sediment cores show a large degree of trace element heterogeneity that varies considerably with geography and provenance ${ }^{11,12}$, and the composition of a recycled sediment may depend on the geography of the subduction zone. More problematic is the issue of temporal variability ${ }^{20,21}$ : the trace 
element budgets of sediments encountered in modern oceans may be poor analogues for the sediments subducted in the past. Finally, the poorly constrained processes operating in subduction zones, including fluid loss and/or melting of sediments, may modify the composition of the subducted sediment component $\mathrm{t}^{22-25}$.

With these caveats aside, we take a simple approach. We assume that the compositions of subducted material are conserved in the subduction zone. Perhaps fluids and melts are removed from the slab and inoculated into the mantle wedge; but the resulting slab residue and the fertilized mantle wedge may in some cases stay together as a package. This package is what enters the general circulation, to eventually be remixed to end up looking like "closed system" slab recycling. While the composition of the original material sent into the subduction zone is underconstrained, we explore whether or not a modern UCC composition, when mixed with the depleted Ta'u source, can generate a suitable source for the Samoan EM2 lava D115-18. We assume that after the depleted Ta'u source mixed completely with the enriched UCC component, the resulting peridotite (treated here as a single lithology) was melted in a modal, aggregated fractional melting system. The modal abundances of the mantle phases, the contribution of UCC to the depleted Ta'u source, and the degree of melting (and the proportion of garnet and spinel melting) of the resulting mixture (the EM2 source) are all adjusted to generate a trace element spidergram that is similar to the enriched Samoan EM2 basalts. The combination of these parameters that generates a "best-fit" spidergram to the Samoan EM2 lava composition is given in Supplementary Table 2. The agreement between the model spidergram and the spidergram for Samoan EM2 lava D115-18 is optimized (the 
fit is within $14 \%$ for all the trace elements considered, or $\sim 11 \%$ if $\mathrm{U}$ is excluded) when the contribution of the UCC component is $\sim 5 \%$.

Having fixed the proportions of UCC (5\%) and the depleted Ta'u source (95\%) in the EM2 source sampled by lava D115-18 (with ${ }^{87} \mathrm{Sr} /{ }^{86} \mathrm{Sr}$ and ${ }^{143} \mathrm{Nd} /{ }^{144} \mathrm{Nd}$ of 0.718592 and 0.512314 , respectively), we use trace element budgets and isotopic constraints to calculate the ${ }^{87} \mathrm{Sr} /{ }^{86} \mathrm{Sr}$ and ${ }^{143} \mathrm{Nd} /{ }^{144} \mathrm{Nd}$ of the UCC component. Assuming a measured isotopic $\left({ }^{87} \mathrm{Sr} /{ }^{86} \mathrm{Sr}=0.704650\right.$ and $\left.{ }^{143} \mathrm{Nd} /{ }^{144} \mathrm{Nd}=0.512789\right)$ and calculated trace element composition (Supplementary Table 1) of the Ta'u source and a trace element composition of $\mathrm{UCC}^{12}$, we calculate the Sr and Nd isotopic composition of the UCC component in the Samoan plume to be 0.7421 and 0.5117 , respectively. The ${ }^{87} \mathrm{Sr} /{ }^{86} \mathrm{Sr}$ and ${ }^{143} \mathrm{Nd} /{ }^{144} \mathrm{Nd}$ values calculated for the UCC endmember in the Samoan plume are within the range of values measured in ancient UCC shield rocks ${ }^{26}$ (Supplementary Figure 2).

While the addition of UCC to the depleted Ta'u source generates a spidergram that is a close match to Samoan EM2 lavas, the fit is not perfect. In particular, the element that exhibits the least perfect fit to the data is U. Samoan EM2 lavas have lower $\mathrm{U}$ concentrations than the model result, and the disagreement may be a result of U-loss during weathering (note the high Th/U in sample D115-18; Supplementary Table 3). Addressing contamination by marine sediment. Implicit in the model of the EM2 source is the assumption that the sediment signature in the Samoan EM2 lavas is a primary mantle signal and not a result of shallow-level sediment contamination. A plot of $\Delta^{207} \mathrm{~Pb} /{ }^{204} \mathrm{~Pb}-\Delta^{208} \mathrm{~Pb} /{ }^{204} \mathrm{~Pb}$ (see Main Text Figure 4) indicates that sediment contamination is not an issue. Further evidence comes from ${ }^{87} \mathrm{Sr} /{ }^{86} \mathrm{Sr}$ measurements in sediments from the Samoan region, which exhibit ${ }^{87} \mathrm{Sr} /{ }^{86} \mathrm{Sr}$ ratios (0.70614 to 0.70824) 
that are much lower than the most enriched Samoan EM2 lavas $(0.72047$ in whole-rock sample D115-21). It is very difficult to generate the high ${ }^{87} \mathrm{Sr} /{ }^{86} \mathrm{Sr}$ observed in the new Samoan EM2 lavas by sediment contamination. For example, the GLOSS average ${ }^{87} \mathrm{Sr} /{ }^{86} \mathrm{Sr}$ composition is only $0.7173(327 \mathrm{ppm} \mathrm{Sr}){ }^{11}$, a value that is much lower than the most isotopically-enriched lavas from Samoa. Even if the most isotopically-enriched marine sediment $\left({ }^{87} \mathrm{Sr} /{ }^{86} \mathrm{Sr}=0.73493,251 \mathrm{ppm} \mathrm{Sr}\right)$ in the compilation from ref. 11 were added to the least isotopically-enriched submarine Savai'i lava $\left({ }^{87} \mathrm{Sr} /{ }^{86} \mathrm{Sr}=0.705435,374\right.$ ppm Sr), over $60 \%$ sediment assimilation would be required to generate the most radiogenic ${ }^{87} \mathrm{Sr} /{ }^{86} \mathrm{Sr}$ observed in the Samoan lavas. Such large quantities of sediment are not visible in the trace element spidergrams of the most enriched Samoan lavas.

In general, Samoan lavas do not show a correlation between ${ }^{87} \mathrm{Sr} /{ }^{86} \mathrm{Sr}$ and $\mathrm{SiO}_{2}$ (Supplementary Figure 4). However, ${ }^{87} \mathrm{Sr} /{ }^{86} \mathrm{Sr}$ ratios in whole-rock lavas from dredge D115 do correlate with $\mathrm{SiO}_{2}$. Having ruled out sediment assimilation using $\mathrm{Sr}$ and $\mathrm{Pb}$ isotope data, the ${ }^{87} \mathrm{Sr} /{ }^{86} \mathrm{Sr}-\mathrm{SiO}_{2}$ array formed by ALIA D115 samples is interpreted to be a result of magma mixing between an evolved (high $\mathrm{SiO}_{2}$ ), isotopically-enriched magma and a less evolved, less isotopically-enriched magma. Other major and trace element data are consistent with this scenario (see Supplementary Figure 4). Perhaps the isotopically-enriched magmatic endmember evolved by crystal fractionation in a magma chamber and, just before eruption, mixed with a later pulse of a less evolved, less isotopically-enriched magma. Magma mixing is not an uncommon phenomenon; heterogeneous ${ }^{87} \mathrm{Sr} /{ }^{86} \mathrm{Sr}$ ratios recorded in olivine-hosted melt inclusions from individual Samoan basalt samples suggest that mixing of magmas from isotopically-distinct sources is not uncommon in $\mathrm{Samoa}^{27}$. 
Data sources for HIMU and EM1 lavas. In Fig. 2 and Fig. 4 of the main text, trace element and $\mathrm{Pb}$-isotope data for the HIMU endmember are from samples collected at Mangaia and Tubuai islands and are reported in refs. 41 and 42. Trace element and Pbisotope data from the EM1 endmember are from samples collected at Pitcairn and include data from ref. 43 and unpublished data (S.R. Hart and E.H. Hauri). Only data from the freshest, most isotopically-extreme samples were used. 


\section{References Cited}

1. White, W.M. \& Hofmann, A.W. Sr and Nd isotope geochemistry of oceanic basalts and mantle evolution. Nature 296, 821-825 (1982).

2. Zindler, A. \& Hart, S.R. Chemical Geodynamics. Ann. Rev. Earth Planet. Sci. 14, 493$571(1986)$.

3. Allegre, C.J. \& Turcotte, D.L. Geodynamic mixing in the mesosphere boundary layer and the origin of oceanic islands. Geophys. Res. Lett. 12, 207-210 (1985).

4. Cohen, R.S. \& O'Nions, R.K. Identification of recycled continental material in the mantle from $\mathrm{Sr}, \mathrm{Nd}$ and $\mathrm{Pb}$ isotope investigations. Earth Planet. Sci. Lett. 61, 73-84 (1982).

5. Hawkesworth, C.J., Norry, M.J., Roddick, J.C. \& Vollmer, R. ${ }^{143} \mathrm{Nd} /{ }^{144} \mathrm{Nd}$ and ${ }^{87} \mathrm{Sr} /{ }^{86} \mathrm{Sr}$ ratios from the Azores and their significance in LIL-element enriched mantle. Nature 280, 28-31 (1979).

6. Hofmann, A.W. Mantle geochemistry: The message from oceanic volcanism. Nature 385, 219-229 (1997).

7. Weaver, B.L. The origin of ocean island basalt end-member compositions: Trace element and isotopic constraints. Earth Planet. Sci. Lett. 104, 381-397 (1991).

8. Workman, R.K. et al. Recycled metasomatized lithosphere as the origin of the Enriched Mantle II (EM2) endmember: evidence from the Samoan volcanic chain. Geochem. Geophys. Geosyst. 5, 10.1029/2003GC000623 (2004).

9. Podosek, F.A., Honda, M. \& Ozima M. Sedimentary noble gases. Geochim. Cosmochim. Acta 44, 1875-1884 (1980). 
10. Ballentine, C.J. \& Burnard, P.G. Production, release and transport of noble gases in the continental crust. Rev. Min. Geochem. 47, 481-538 (2002).

11. Plank, T. \& Langmuir, C.H. The chemical composition of subducting sediment and its consequences for the crust and mantle. Chemical Geology 145, 325-394 (1998).

12. Rudnick, R. L. \& Gao, S. in The Crust (ed. Rudnick, R. L.) 1-64, Vol. 3 of Treatise in Geochemistry (Elsevier, Amsterdam, 2003).

13. Peucker-Ehrenbrink, B. \& Jahn, B.M. Rhenium osmium isotope systematics and platinum group element concentrations: Loess and the upper continental crust, Geochem. Geophys. Geosyst. 2, 10.1029/2001GC000172 (2001).

14. Becker, H. et al. Highly siderophile element composition of the Earth's primitive upper mantle: constraints from new data on peridotite massifs and xenoliths. Geochim. Cosmochim. Acta. 70, 4528-4550 (2006).

15. Zartman, R.E. \& Doe, B.R. Plumbotectonics-The model. Tectonophysics 75, 135$142(1981)$.

16. Kelemen, P.B., Yogodzinski, G.M. \& Scholl, D.W. in Inside the Subduction Factory (ed Eiler, J.) 223-276 (Geophys. Monogr. 138, AGU, Washington DC, 2004).

17. Hart, S. R. A large-scale isotope anomaly in the Southern Hemisphere mantle. Nature 309, 753-57 (1984).

18. Salters, V. Coupled Trace Element and Isotope Variations in Oceanic Basalts: recycling re-examined. EOS 86, Abstract V41D-1486 (2005).

19. Hart, S.R. \& Gaetani, G.A. Mantle Pb paradoxes: the sulfide solution. Contrib. Mineral. Petrol. 152, 295-308 (2006). 
20. Ronov, A.B., Khain, V.E., Balukhovsky, A.N. \& Seslavinsky, K.B. Quantitative analysis of Phanerozoic sedimentation. Sedimentary Geology 25, 311-325 (1980).

21. Wilkinson, B.H. \& Walker, J.C.G. Phanerozoic cycling of sedimentary carbonate. Am. J. Sci. 289, 525-548 (1989).

22. Kelley, K.A., Plank, T., Farr, L., Ludden, J. \& Staudigel, H. Subduction cycling of U, Th, and Pb. Earth Planet. Sci. Lett. 234, 369-383 (2005).

23. Kessel, R., Schmidt, M.W., Ulmer, P. \& Pettke, T. Trace element signature of subduction-zone fluids, melts and supercritical liquids at 120-180 km depth. Nature 437, 724-727 (2005).

24. Johnson, M.C. \& Plank, T. Dehydration and melting experiments constrain the fate of subducted sediments. Geochem. Geophys. Geosyst. 1, 10.1029/1999GC000014 (1999). 25. Elliott, T., Plank, T., Zindler, A., White, W. \& Bourdon, B. Element transport from slab to volcanic front at the Mariana Arc. J. Geophys. Res. 102, 14991-15019 (1997). 26. McColluch, M.T. \& Wasserburg, G.J. Sm-Nd and Rb-Sr chronology of continental crust formation. Science 200, 1003-1011 (1978).

27. Jackson, M.G. \& Hart, S.R. Strontium isotopes in melt inclusions from Samoan basalts: implications for heterogeneity in the Samoan plume. Earth Planet. Sci. Lett. 245, 260-277 (2006).

28. McDonough, W.F. \& Sun, S.S. The composition of the Earth. Chem. Geol. 120, $223-$ $253(1995)$.

29. Hofmann, A.W. \& White, W.M. Ba, Rb and Cs in the Earth's mantle. Zeitschrift fur Naturforschung 38, 256-266 (1983). 
30. Hart, S.R. \& Blusztajn, J. Age and geochemistry of the mafic sills, ODP site 1276, Newfoundland margin. Chem. Geol. 235, 222-237 (2006).

31. Hooper, P.R. \& Johnson, D.M., Conrey, R.M. Major and trace element analyses of rocks and minerals by automated X-ray spectrometry, Washington State Univ. open-file report, Pullman (1993).

32. Govindaraju, K. Compilation of working values and sample description for 383 geostandards. Geostandards Newsletter 18, 1-158 (1994).

33. Govindaraju, K. Working values with confidence limits for twenty-six CRPG, ANRT and IWG-GIT geostandards. Geostandards Newsletter 19, 1-32 (1995).

34. Taras, B.D. \& Hart, S.R. Geochemical evolution of the New England seamount chain: isotopic and trace-element constraints. Chem. Geol. 64, 35-54 (1987).

35. Galer, S.J.G. Chemical and isotopic studies of crust-mantle differentiation and the generation of mantle heterogeneity, Thesis, Univ. of Cambridge (1986).

36. Abouchami, W., Galer, S.J.G., \& Koschinsky, A. Pb and Nd isotopes in NE Atlantic Fe-Mn crusts: proxies for trace metal paleosources and paleocean circulation. Geochim Cosmochim Acta 63, 1489-1505 (1999).

37. Todt, W., Cliff, R.A., Hanser, A. \& Hofmann, A.W. in Earth Processes: Reading the Isotopic Code Geophysical Monograph (eds Basu, A. \& Hart, S.R.) 429-437 (Geophys. Monogr. 95, AGU, Washington DC, 1996).

38. Hart, S.R., Workman, R.K., Coetzee, M., Blusztajn, J., Ball, L. \& Johnson, K.T.M. The $\mathrm{Pb}$ isotope pedigree of Western Samoan Volcanics: new insights from high-precision analysis by NEPTUNE ICP/MS. EOS 83, Abstract F20 (2002). 
39. Kurz, M.D., Curtice, J.C., Lott, D.E. \& Solow, A. Rapid helium isotopic variability in Mauna Kea shield lavas from the Hawaiian Scientific Drilling Project. Geochem. Geophys. Geosyst. 4, 10.1029/2002GC000439 (2004).

40. Farley, K.A., Natland, J.H. \& Craig, H. Binary mixing of enriched and undegassed (primitive?) mantle components ( $\mathrm{He}, \mathrm{Sr}, \mathrm{Nd}, \mathrm{Pb})$ in Samoan lavas. Earth Planet. Sci. Lett. 111 193-199 (1992).

41. Hauri, E.H. \& Hart, S.R. Re-Os isotope systematics of HIMU and EMII oceanic island basalts from the south Pacific Ocean. Earth Planet. Sci. Lett. 114, 353-371 (1993). 42. Woodhead, J.D. Extreme HIMU in an oceanic setting: the geochemistry of Mangaia Island (Polynesia), and temporal evolution of the Cook-Austral hotspot. J. Volcanol. Geotherm. Res. 72, 1-19 (1996).

43. Eisele, J., Sharma, M., Galer, S.J.G., Blichert-Toft, J., Devey, C.W. \& Hofmann, A.W. The role of sediment recycling in $\mathrm{EM}-1$ inferred from $\mathrm{Os}, \mathrm{Pb}, \mathrm{Hf}, \mathrm{Nd}, \mathrm{Sr}$ isotope and trace element systematics of the Pitcairn hotspot. Earth Planet. Sci. Lett. 196, 197$212(2002)$ 


\section{Supplementary Figures}

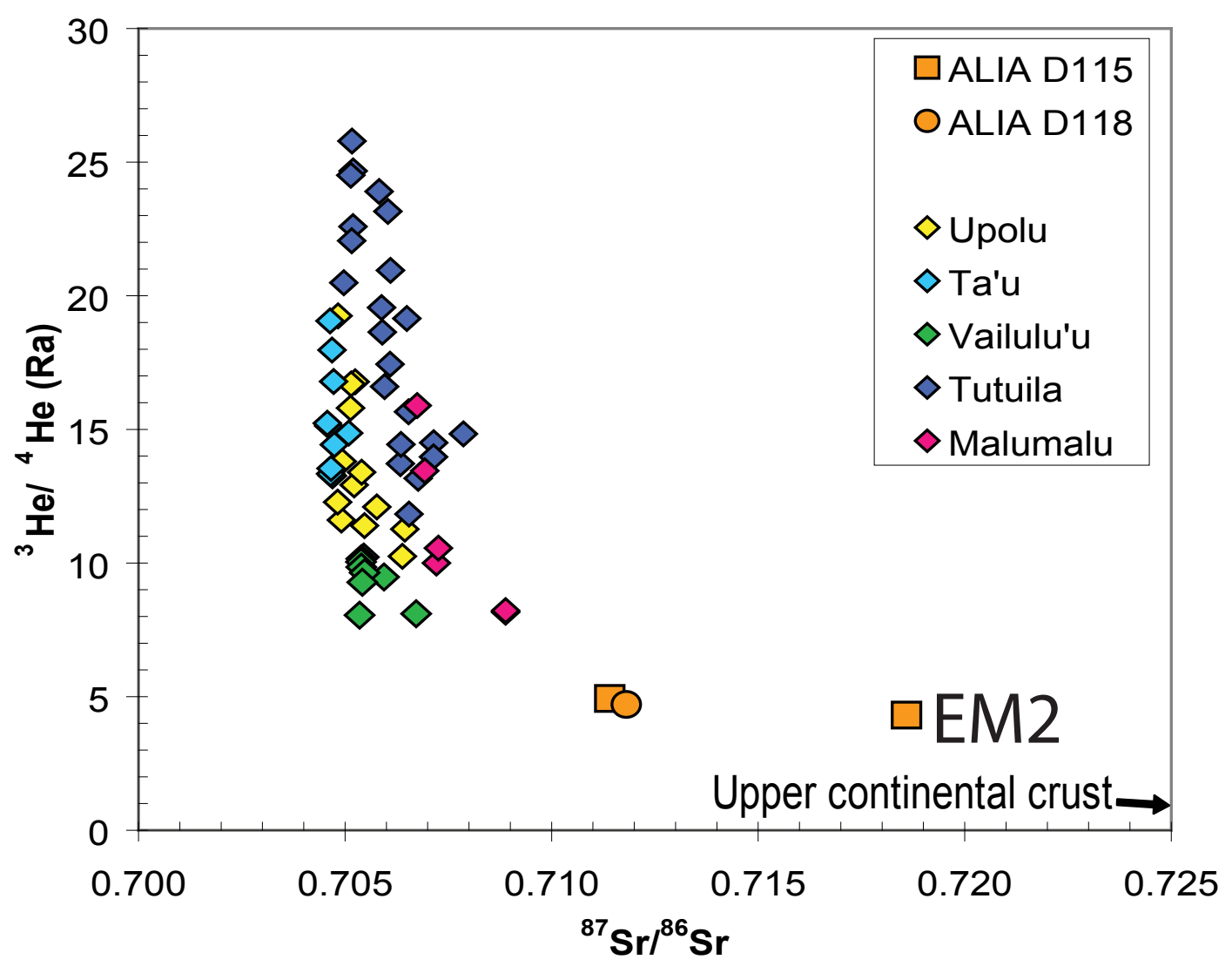

Supplementary Figure $1{ }^{87} \mathrm{Sr} /{ }^{86} \mathrm{Sr}$ vs. ${ }^{3} \mathrm{He} /{ }^{4} \mathrm{He}$ isotopes in Samoan basalts. New ${ }^{3} \mathrm{He} /{ }^{4} \mathrm{He}$ ratios in the enriched Samoan EM2 basalts are low $(<5 \mathrm{Ra})$, and plot on a trajectory that extrapolates to a UCC component with low ${ }^{3} \mathrm{He} /{ }^{4} \mathrm{He}$ $(0.007 \mathrm{Ra})^{10}$ and high ${ }^{87} \mathrm{Sr} /{ }^{86} \mathrm{Sr}(0.7421)$. Data for the other Samoan islands and seamounts are from refs 8 and 40 . 


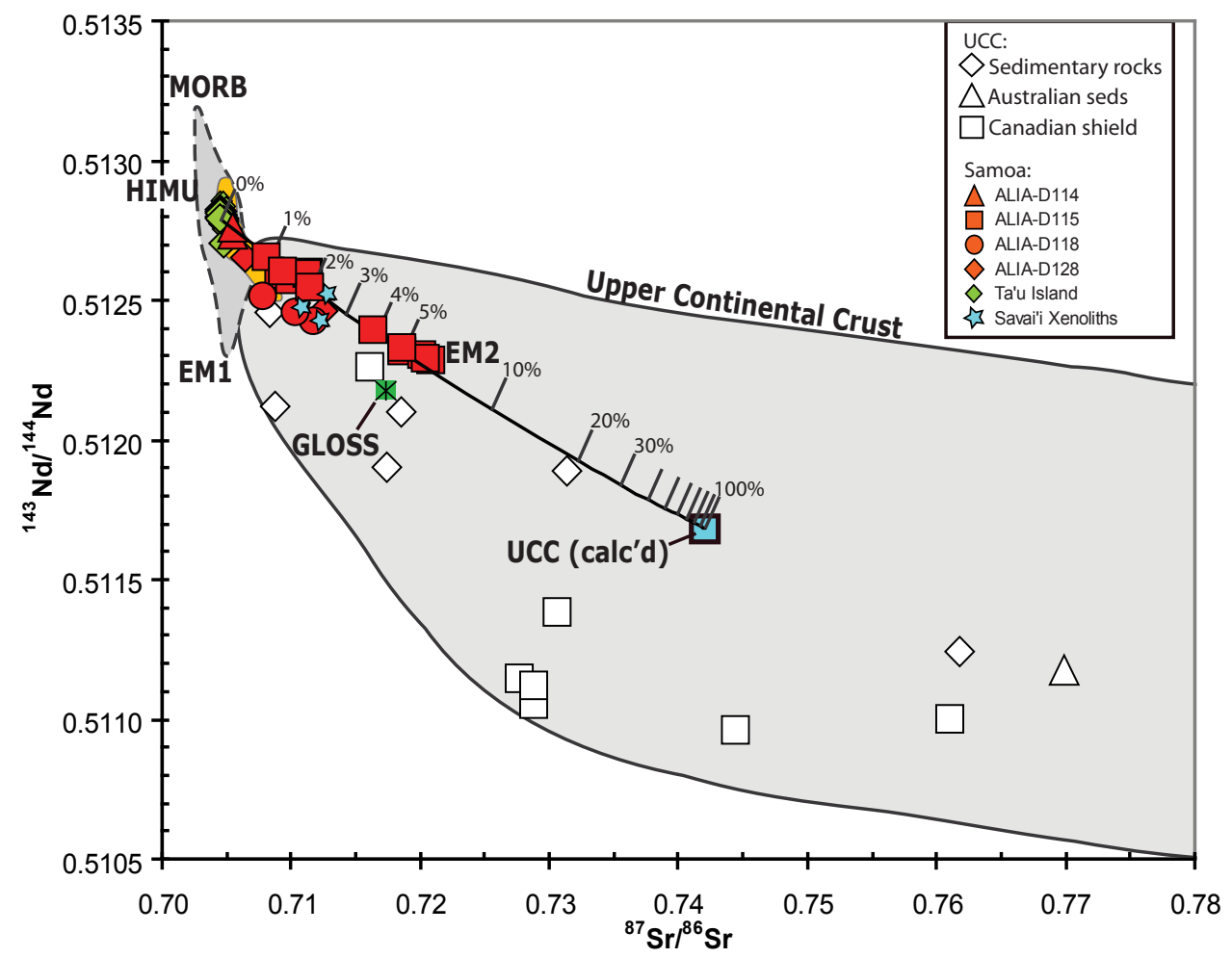

Supplementary Figure $2{ }^{87} \mathrm{Sr} /{ }^{86} \mathrm{Sr}$ vs. ${ }^{143} \mathrm{Nd} /{ }^{144} \mathrm{Nd}$ of Samoan shield basalts compared with samples from upper continental crust (UCC) from ref. 26. The grey field (with solid outline) encompasses $\mathrm{Sr}$ and Nd isotopic analyses on UCC samples $^{26}$, and extends outside of the figure to values of 1.1862 and 0.51023 , respectively. The grey field (with dashed outline) encompasses the non-Samoan OIB field. The orange field describes Samoan shield basalts observed in previous studies; the new Samoan EM2 basalts (red) extend well into the field for UCC. Tic marks represent addition of the UCC component to the depleted peridotite Ta'u source. The isotopic composition of the UCC endmember in the Samoan plume is calculated to have ${ }^{87} \mathrm{Sr} /{ }^{86} \mathrm{Sr}$ and ${ }^{143} \mathrm{Nd} /{ }^{144} \mathrm{Nd}$ of 0.7421 and 0.5117, respectively (light blue box, see Supplementary Discussion), and lies in the range of values previously measured on UCC rocks ${ }^{26} .5 \%$ of this hypothetical UCC composition is required to generate the spidergram of Samoan sample D115-18 (and an estimated 6\% UCC is required to generate the ${ }^{87} \mathrm{Sr} /{ }^{86} \mathrm{Sr}$ ratios in the most enriched cpx from sample D115-21). 


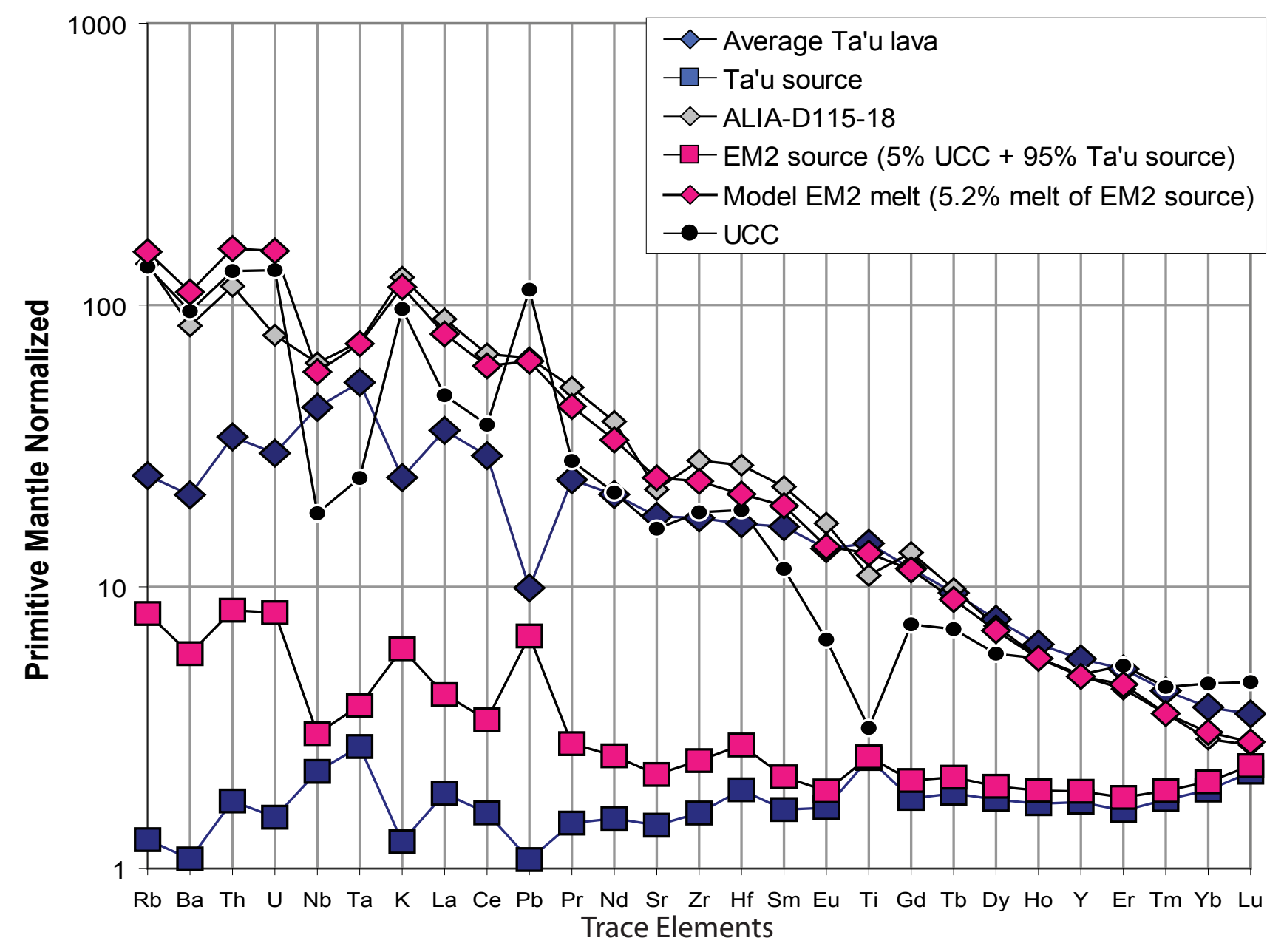

Supplementary Figure 3 Primitive mantle ${ }^{28}$ normalized trace element patterns for Samoan basalts and peridotite sources. These compositions are used in a sediment recycling model for generating a Samoan EM2 mantle source. Ta'u lavas are assumed to be melts of a depleted plume component, and the average, olivine-fractionation corrected Ta'u lava composition is plotted. A Ta'u source for the average Ta'u lava is calculated to satisfy isotopic constraints. $5 \%$ of $U C C^{12}$ is added to $95 \%$ of the Ta'u source to make the EM2 source sampled by the Samoan lava D115-18, and the model melt of the EM2 peridotite source is plotted. The spidergram of the model melt is similar to sample D115-18 (the second most isotopically-enriched Samoan sample). The most isotopicallyenriched lava, D115-21, is too evolved to reliably reconstruct its trace element composition. Plotted compositions can be found in Supplementary Tables $1 \& 2$. 

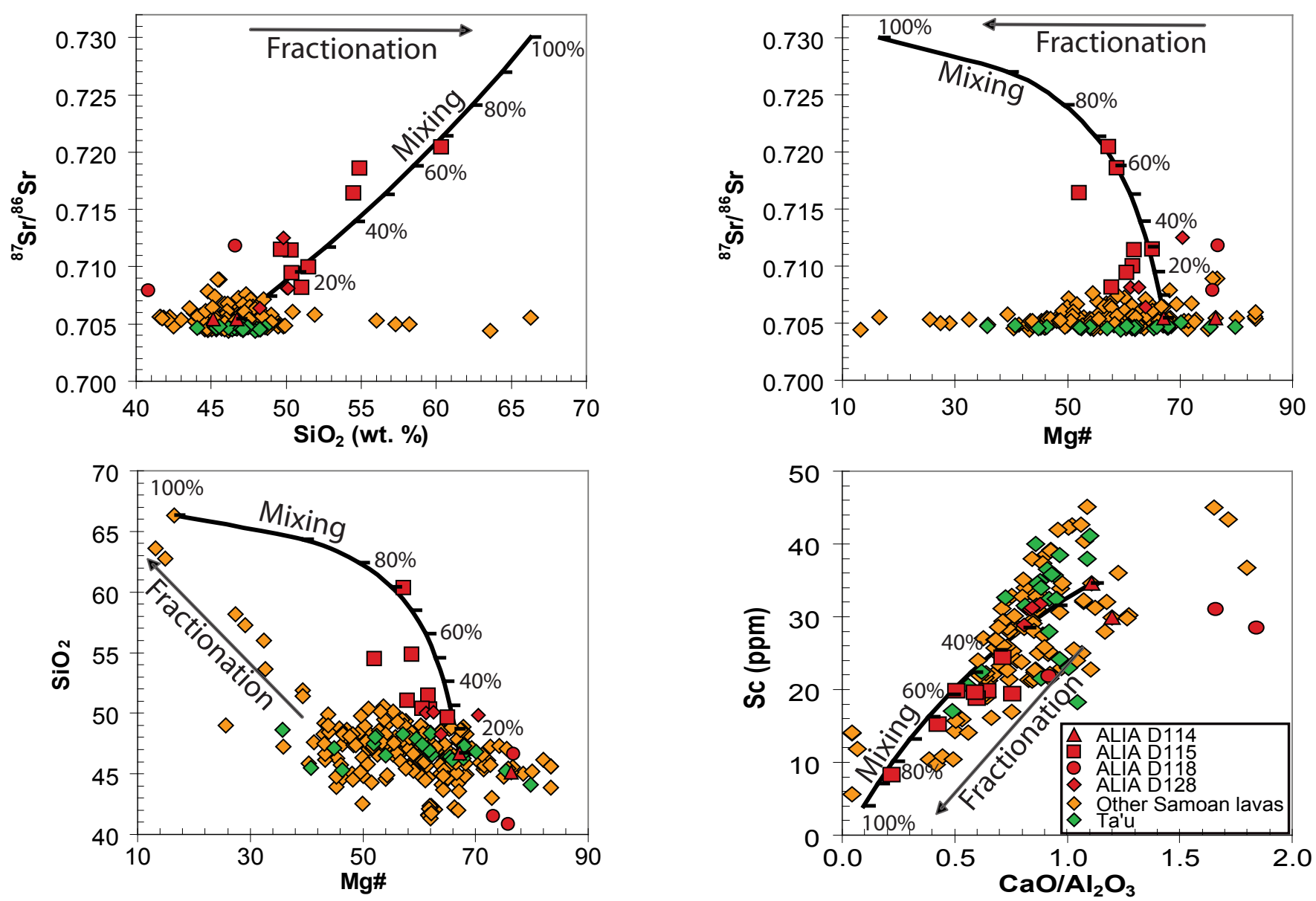

Supplementary Figure 4 A model for the co-variation of $\mathrm{SiO}_{2}$ and ${ }^{87} \mathrm{Sr} /{ }^{86} \mathrm{Sr}$ in ALIA D115 samples. Samoan lavas do not exhibit a one-to-one relationship between $\mathrm{SiO}_{2}$ (or $\mathrm{Mg \#}$ ) and ${ }^{87} \mathrm{Sr} /{ }^{86} \mathrm{Sr}$; evolved Samoan lavas exhibit both high (up to 0.7205 ) and low $(0.7044){ }^{87} \mathrm{Sr} /{ }^{86} \mathrm{Sr}$ ratios. However, lavas from dredge ALIA D115 exhibit a correlation between ${ }^{87} \mathrm{Sr} /{ }^{86} \mathrm{Sr}$ and $\mathrm{SiO}_{2}$. We explain this correlation in ALIA D115 lavas as a result of mixing between a highly evolved, isotopically-enriched magma and a less evolved, less isotopically-enriched magma. In this scenario, the mixing endmembers are a Savai'i submarine lava sample (ALIA D114-01; Supplementary Table 3) and a highly evolved lava from Tutuila (91TP-128; $\mathrm{SiO}_{2}=66.30$ wt. $\%, \mathrm{MgO}=0.41$ wt. $\%, \mathrm{FeO}=4.06$ wt. $\%, \mathrm{CaO}=1.62$ wt. $\%, \mathrm{Al}_{2} \mathrm{O}_{3}=17.03$ wt. \%, $\mathrm{Sr}=395 \mathrm{ppm}$; Natland unpubl. data). The measured ${ }^{87} \mathrm{Sr} /{ }^{86} \mathrm{Sr}$ of the Tutuila lava is $0.705535^{8}$. However, for the sake of argument, this sample is given an ${ }^{87} \mathrm{Sr} /{ }^{86} \mathrm{Sr}$ ratio of 0.730 in the mixing model in order to determine whether mixing between an evolved magma and a less evolved magma can generate a mixing array consistent with the data from dredge ALIA D115. Sc was not measured on the Tutuila lava, but its concentration is assumed to be $4 \mathrm{ppm}$. The reduction of $\mathrm{Sc}$ and $\mathrm{CaO} / \mathrm{Al}_{2} \mathrm{O}_{3}$ (including reduced Mg\#'s and increased $\mathrm{SiO}_{2}$ ) in the most isotopically-enriched lavas from ALIA D115 is consistent with cpx fractionation. Crystal fractionation of an isotopically-enriched magma followed by mixing with a less evolved, less isotopically-enriched magma describes the geochemical data from dredge ALIA D115. 


\section{Supplementary Tables}

\section{Supplementary Table 1. Calculation of the depleted component in the Samoan plume, using lavas from Ta'u island}

\begin{tabular}{|c|c|c|c|c|c|c|}
\hline & $\begin{array}{l}\text { Primitive } \\
\text { mantle }^{1}\end{array}$ & $\begin{array}{c}\text { Avg. Ta'u lava }{ }^{2} \\
\text { (olivine corr'd to } \text { Fogo }_{90}\end{array}$ & $\begin{array}{c}\text { Variability in } 18 \text { Ta'u lavas } \\
(1 \sigma, \text { std. dev., \%) }\end{array}$ & $\begin{array}{c}\text { Bulk partition coefs }{ }^{3} \\
\text { (garnet field) }\end{array}$ & $\begin{array}{c}\text { Bulk partition coefs }^{3} \\
\text { (spinel field) }\end{array}$ & $\begin{array}{c}\text { Depleted Ta'u source } \\
\text { (calculated from avg. Ta'u lava) }\end{array}$ \\
\hline $\mathrm{Rb}$ & 0.6 & 14.9 & 16.5 & 0.000144 & 0.000124 & 0.759 \\
\hline $\mathrm{Ba}$ & 6.6 & 140 & 11.9 & 0.000144 & 0.000124 & 7.14 \\
\hline Th & 0.0795 & 2.71 & 13.4 & 0.00219 & 0.00178 & $0.138(0.117)^{5}$ \\
\hline$U$ & 0.0203 & 0.61 & 12.7 & 0.00074 & 0.00018 & 0.0309 \\
\hline $\mathrm{Nb}$ & 0.658 & 28.53 & 11.5 & 0.00393 & 0.00302 & 1.45 \\
\hline $\mathrm{Ta}$ & 0.037 & 1.97 & 11.7 & 0.00393 & 0.00302 & 0.10 \\
\hline $\mathrm{K}$ & 240 & 5860 & 9.8 & 0.00150 & 0.00128 & 299 \\
\hline $\mathrm{La}$ & 0.648 & 23.27 & 11.0 & 0.0114 & 0.00983 & 1.20 \\
\hline $\mathrm{Ce}$ & 1.675 & 48.93 & 10.3 & 0.0191 & 0.0161 & 2.64 \\
\hline $\mathrm{Pb}$ & 0.15 & 1.49 & 18.4 & 0.0834 & 0.0816 & 0.161 \\
\hline $\mathrm{Pr}$ & 0.254 & 6.09 & 10.0 & 0.0314 & 0.0247 & 0.368 \\
\hline $\mathrm{Nd}$ & 1.25 & 26.58 & 9.1 & 0.0463 & 0.0357 & 1.88 \\
\hline $\mathrm{Sr}$ & 19.9 & 354.1 & 9.9 & 0.0665 & 0.0364 & 28.3 \\
\hline $\mathrm{Zr}$ & 10.5 & 184 & 9.9 & 0.0867 & 0.0371 & 16.5 \\
\hline $\mathrm{Hf}$ & 0.283 & 4.74 & 9.0 & 0.114 & 0.0607 & 0.538 \\
\hline $\mathrm{Sm}$ & 0.406 & 6.64 & 7.8 & 0.0868 & 0.0574 & 0.657 \\
\hline $\mathrm{Eu}$ & 0.154 & 2.10 & 7.9 & 0.121 & 0.0671 & 0.253 \\
\hline $\mathrm{Ti}$ & 1205 & 17190 & 7.4 & 0.176 & 0.122 & 2960 \\
\hline $\mathrm{Gd}$ & 0.544 & 6.32 & 7.8 & 0.179 & 0.0769 & 0.965 \\
\hline $\mathrm{Tb}$ & 0.099 & 0.94 & 8.1 & 0.254 & 0.0876 & 0.18 \\
\hline Dy & 0.674 & 5.17 & 8.2 & 0.316 & 0.0964 & 1.18 \\
\hline Ho & 0.149 & 0.93 & 8.1 & 0.402 & 0.0972 & 0.25 \\
\hline$Y$ & 4.30 & 23.86 & 7.3 & 0.475 & 0.102 & 7.40 \\
\hline $\mathrm{Er}$ & 0.438 & 2.24 & 7.3 & 0.481 & 0.105 & 0.70 \\
\hline $\mathrm{Tm}$ & 0.068 & 0.29 & 7.2 & 0.673 & 0.110 & 0.12 \\
\hline $\mathrm{Yb}$ & 0.441 & 1.65 & 7.1 & 0.865 & 0.115 & 0.84 \\
\hline Lu & 0.0675 & 0.24 & 7.5 & 1.09 & 0.124 & 0.148 \\
\hline
\end{tabular}

${ }^{1}$ Primitive mantle is from ref 28.

${ }^{2}$ Ta'u basalts (with MgO > 6.5 wt.\%) used in the average lava composition include: T10, T16, T19, T22, T23, T25, T30, T32, T33, T44, T45, T46, T47, T48, T51, T54, T55, and 74-1. T14 is suspected of $\mathrm{Pb}$ contamination and is not included. The 18 Ta'u basalts were individually corrected for olivine fractionation to be in equilibrium with a mantle olivine composition of $\mathrm{Fo}_{90}$ (assuming $\mathrm{Fe}^{2+} / \mathrm{Fe}_{\text {total }}$ is 0.90 ), trace element corrected, and then averaged.

${ }^{3}$ Bulk partition coefficients are calculated by assuming the following modal abundances: spinel stability field: $3.72 \%$ spinel, $17.8 \%$ clinopyroxene, $26 \%$ orthopyroxene, $52.39 \%$ olivine, $0.162 \%$ sulfide; garnet stability field: $10.7 \%$ garnet, $20.8 \%$ clinopyroxene, $13.4 \%$ orthopyroxene, $55.1 \%$ olivine, $0.161 \%$ sulfide. Mineral-melt partition

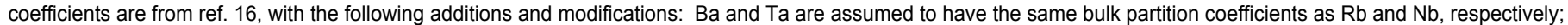
$\mathrm{Tm}$ and $\mathrm{Sr}$ are assumed to have a bulk partition coefficient that is the average of the elements that bracket them on the spidergram; the sulfide-melt partition coefficient for $\mathrm{Pb}$ is assumed to be 42 . The mineral modes in the garnet and spinel stability fields are calculated to agree with a primitive mantle major element composition. Although the Ta'u source is slightly depleted, and therefore has suffered a small amount of melt extraction during its history, the low degree of melt extraction will not significanlty change the calculated mineral modes.

${ }^{4}$ The Ta'u source assumes that the average, olivine-fractionation corrected Ta'u lava resulted from a $5.1 \%$ modal aggregated fractional melt with a $50.6 \%$ melt contribution from the garnet stability field (and the remainder from the spinel stability field). This precise set of melting parameters allows the parent-daughter ratios (Lu/Hf and Sm/Nd)

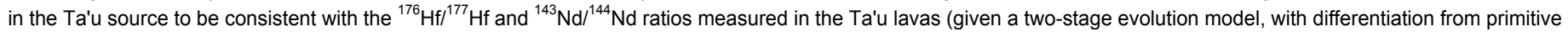
mantle at $1.8 \mathrm{Ga})$.

${ }^{5}$ The Th concentration in parenthesis, which yields a Th/Pb ratio of 0.727 , provides a value required for the Ta'u source to be consistent with constraints from ${ }^{208} \mathrm{~Pb} /{ }^{204} \mathrm{~Pb}$ isotopes measured in Ta'u lavas. The other Th value for the Ta'u source is calculated by adjusting the modal sulfide abundance to give U/Pb ratios that are consistent with ${ }^{206} \mathrm{~Pb} /{ }^{204} \mathrm{~Pb}$ and ${ }^{207} \mathrm{~Pb} /{ }^{204} \mathrm{~Pb}$. This Th svalue $(0.138)$ generates a $\mathrm{Th} / \mathrm{Pb}$ ratio $(0.855)$ that is within error $(18 \%)$ of the measured Th/Pb variability $( \pm 23 \%)$ in Ta'u lavas, and is therefore (within uncertainty of the data available on Ta'u lavas) consistent with measured ${ }^{208} \mathrm{~Pb} /{ }^{204} \mathrm{~Pb}$ ratios. 
Supplementary Table 2. Calculation of the EM2 source for Samoan lava sample D115-18.

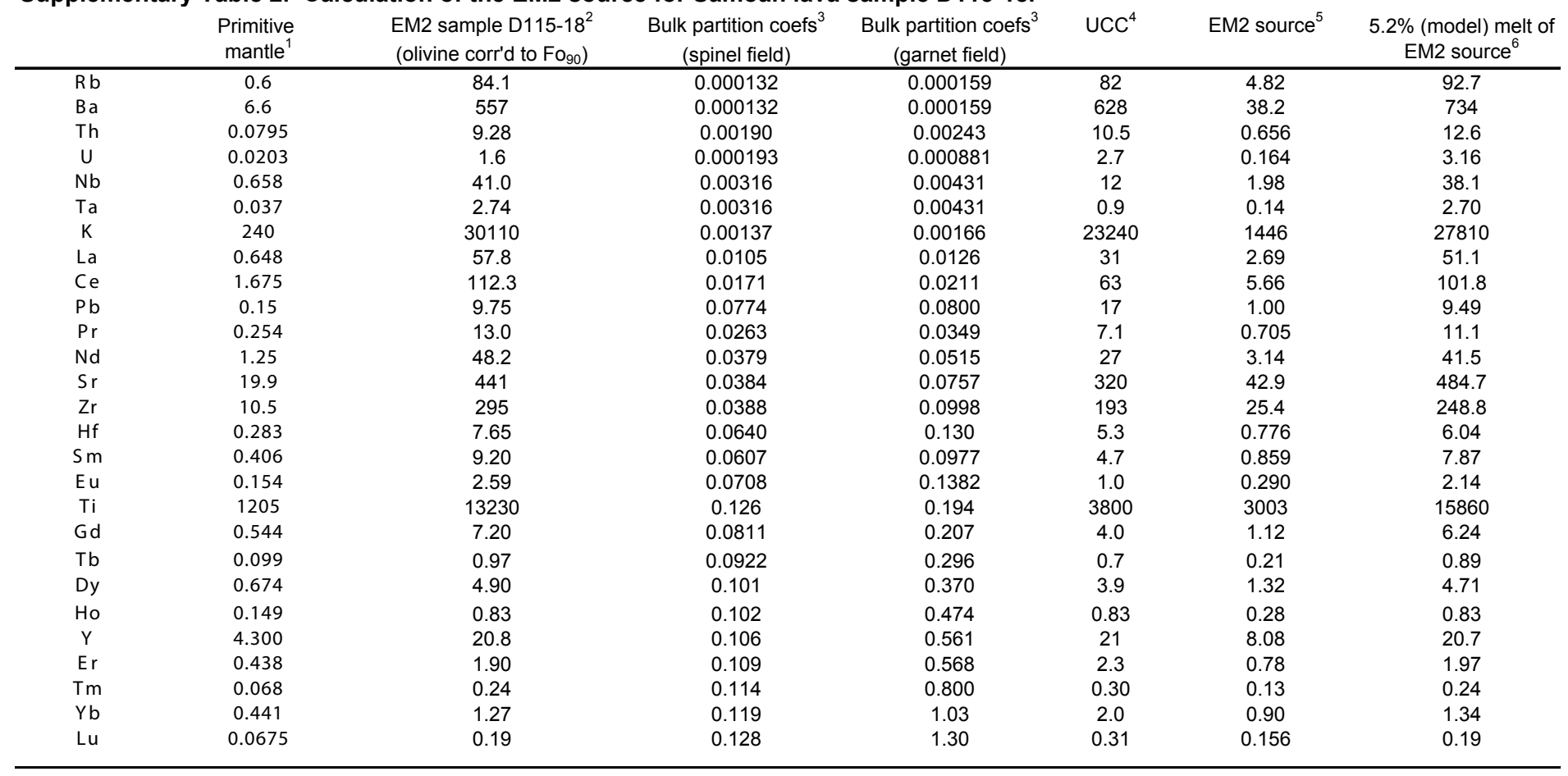

${ }^{1}$ Primitive mantle is from ref. 28.

${ }^{2}$ This EM2 lava composition is the olivine-fractionation corrected (to $\mathrm{Fo}_{90}$ ) trace element composition of sample D115-18, the second most is otopically-enriched lava from Samoa. The most is otopically-enriched lava (D115-21) is too evolved (MgO =3.6\%) to reliably correct for cyrstal fractionation.

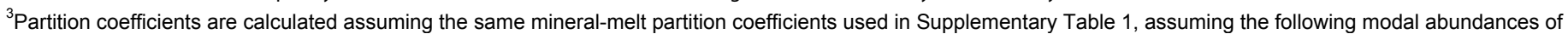
mantle phases: garnet stability field (13.0\% garnet, $23.0 \%$ clinopyroxene, $10.85 \%$ orthopyroxene, $53.0 \%$ olivine, $0.15 \%$ sulfide); spinel stability field (4.5\% spinel, $19.0 \%$ clinopyroxene, $25.35 \%$ orthopyroxene, $51.0 \%$ olivine, $0.15 \%$ sulfide).

${ }^{4}$ Upper continental crust (UCC) is from ref. 12.

${ }^{5} \mathrm{C}$ alculated by adding $5 \%$ UCC to $95 \%$ of the Ta'u source (the Ta'u source is reported in S upplementary Table 1).

${ }^{6}$ This composition is calculated by melting the EM2 source by $5.2 \%$. A modal aggregated fractional melting model is assumed, which uses the bulk partition coefficients from this table, and assumes a $59 \%$ melt contribution from the garnet stability field and $41 \%$ from the spinel stability field. We arrive at this set of melting parameters by optimizing the fit between the spidergrams of the EM2 lava D115-18 and the model EM2 melt. 


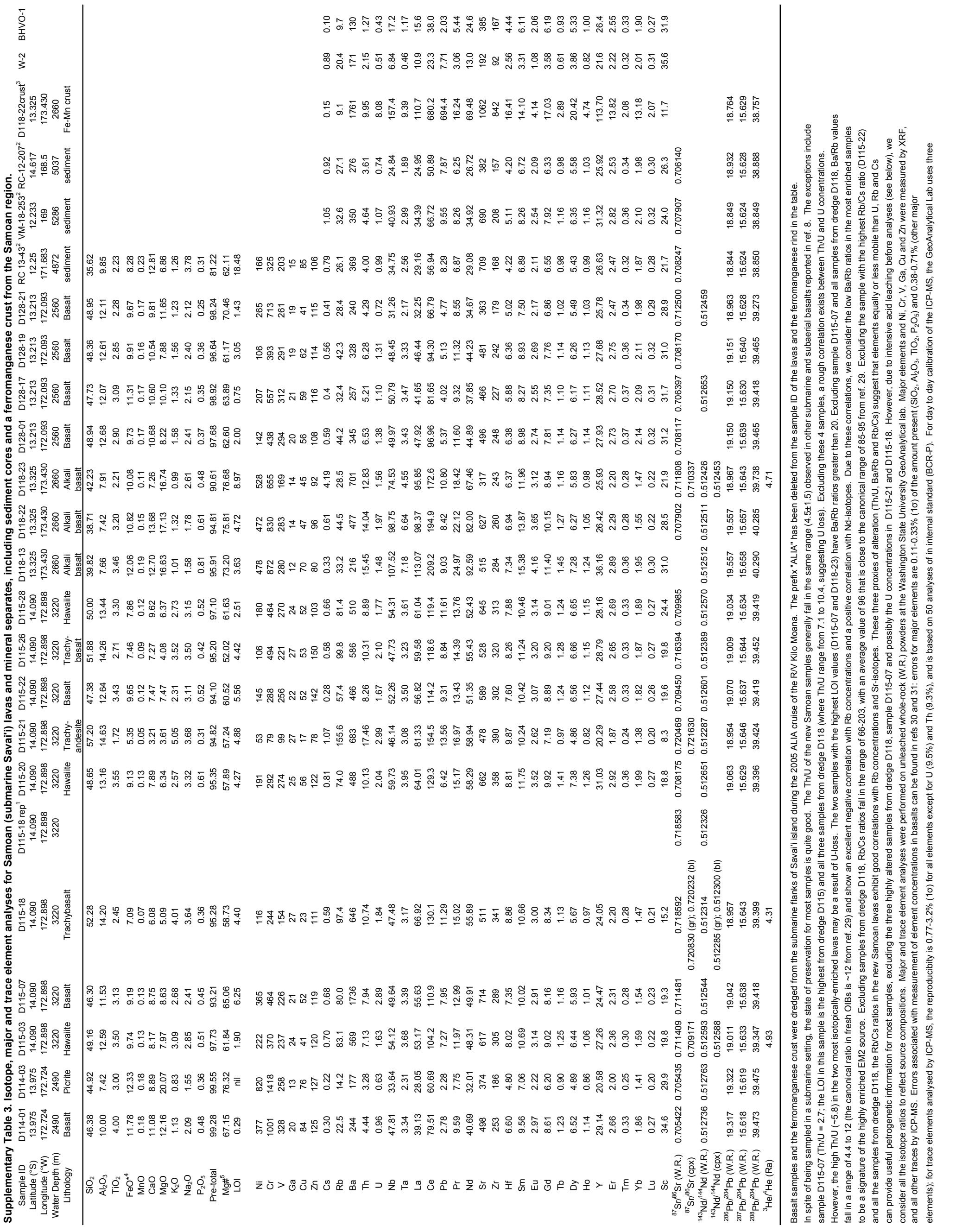




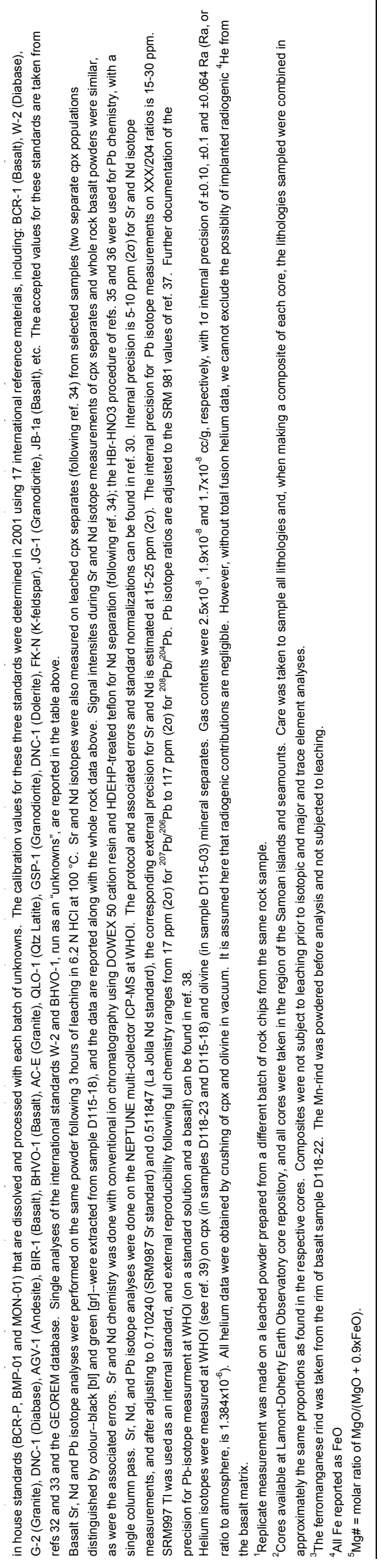

